\title{
Risk factors for sporadic hepatitis A infection: A systematic review and meta-analysis
}

\author{
Anne Thébault ${ }^{\mathrm{a}, *}$, Anne-Marie Roque-Afonso ${ }^{\mathrm{b}}$, Pauline Kooh ${ }^{\mathrm{a}}$, Vasco Cadavez $^{\mathrm{c}}$, \\ Ursula Gonzales-Barron $^{c}$, Nicole Pavio ${ }^{\mathrm{d}}$ \\ ${ }^{\text {a }}$ Risk Assessment Department, French Agency for Food, Environmental and Occupational Health and Safety (ANSES), Maisons-Alfort, France \\ ${ }^{\mathrm{b}}$ Université Paris-Saclay, Inserm 1193 Physiopathogénèse et Traitement des Maladies du Foie, Hôpital Paul Brousse, 94800, Villejuif, France

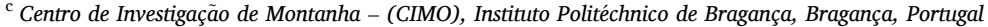 \\ d ANSES, Animal Health Laboratory, UMR 1161 VIROLOGIE INRA, ENVA, Maisons-Alfort, France
}

\section{A R T I C L E I N F O}

\section{Keywords:}

Research synthesis

Case-control studies

Cohort studies

Meta-regression

HAV

\begin{abstract}
A B S T R A C T
Hepatitis A virus (HAV) is responsible for common acute viral hepatitis worldwide. Improvement in sanitation and use of efficient vaccines have reduced HAV incidence in developed countries. However, naive adult population are most susceptible to severe outcomes, and high endemic areas persist in developing regions. The transmission of HAV through the fecal-oral route is established. However, considering evolving consumption habits and global market exchange of food, investigations on risk factors associated with HAV infection are needed. Thus, a systematic review and a meta-analysis of case-control, cohort and transversal studies was performed to determine the main risk factors associated with sporadic HAV infection. Relevant scientific articles were identified through systematic literature search and subjected to a methodological quality assessment. Mixed-effects meta-analyses models were adjusted by population type to appropriate data partitions. HAV infections are defined by serological testing. The quality assessment stage selected 78 studies investigating risk factors for sporadic infections with hepatitis A conducted between 1985 and 2013. This meta-analysis confirmed that HAV infections are mostly related to inter-human transmissions, either due to contact with an ill person, through oral-anal sex practice, or lack of personal hygiene. Travel to endemic countries, occupational exposure such as working in child daycare, and exposure to wastewater were associated with HAV infection. As HAV can persist in the environment, it was not surprising that consumption of untreated drinking water, shellfish consumed raw, and crop products were risk factors. Food contamination could be due to the use of contaminated water (fruits, vegetables) or originate from infected food handlers at every point of the food chain (from picking to serving). Eating or drinking outside were associated with HAV infection. A lack of recent case-control studies was identified, with only three studies eligible between 2011 and 2017. Case-control studies required a more precise definition of risk factors such as type of crop product, and storing/preparation information (e.g. washed, frozen). The frequency of consumption or duration of environmental exposure could also better inform relationship between exposure and risk of infection. In a context of epidemiological change of HAV, international travel and trade of foods, future case-control studies are needed and should focus on populations at risk of severe infections and acute cases.
\end{abstract}

\section{Introduction}

About 1.4 million hepatitis cases worldwide, every year (WHO, 2015) are due to hepatitis A virus (HAV). HAV is responsible for acute viral hepatitis in humans after contamination through the fecal-oral route, either through person-to-person contact, or consumption of contaminated food or water. Hepatitis A occurs in cyclic epidemics and is occasionally associated with foodborne outbreaks (WHO, 2020). HAV belongs to the Picornaviridae family, Hepatovirus A genus and has only been isolated in humans and primates. (Taxonomy ICTV: https://talk.ict vonline.org/ictv-reports/ictv_online_report/positive-sense-rna-vi ruses/picornavirales/w/picornaviridae/709/genus-hepatovirus). Based on genomic sequences, HAV is divided into six genotypes, of which genotypes I, II and III, divided into subtypes A and B, infect humans (Robertson et al., 1992).

The incubation of Hepatitis A is usually 14-28 days. Symptoms of

\footnotetext{
* Corresponding author.
} 
hepatitis usually range mild to severe, and atypical extrahepatic manifestations are rare (Lemon et al., 2018). HAV does not cause chronic liver disease (WHO, 2012), however, recovery from the illness requires weeks or months (WHO, 2012).

Only $10 \%$ of infected children under six years of age experience jaundice, whereas most infected older children and adults are symptomatic, including jaundice in more than $70 \%$ of the cases (Lemon et al., 2018). Rare complications, such as fulminant hepatitis can occur. The case-fatality ratio increases with age: from $0.1 \%$ below 15 years of age to 1.8-5.4\% after 50 years old (Lemon et al., 2018).

Anti-HAV IgM seroconversion occurs during the symptomatic phase of acute hepatitis, and declines within 4-6 months. IgM response is a marker of acute HAV hepatitis. Anti-HAV IgG appears concomitantly with anti HAV IgM, but increases more slowly and persists life-long (Walker et al., 2019). Hence, seroprevalence studies are based on antiHAV immunoglobulin G antibodies (IgG).

The incidence of HAV infections varies considerably between countries and is related to the socioeconomic status of the population (Jacobsen and Wiersma, 2010). It has been largely mitigated in regions with access to clean water and sanitation facilities (Jacobsen and Koopman, 2004). The level of endemicity is defined by the prevalence of HAV antibodies ( $\mathrm{IgG}$ ) in a population, taking into account the mean age of acquired infection, a region, or a country (Hollinger and Emerson, 2007). Geographical areas can be characterized by high, intermediate, low, or very low levels of HAV endemicity, reflecting the level of viral circulation and exposure. In countries where HAV is highly endemic, the majority of cases concern children under five year old. In these areas, adults are protected against HAV infection, due to a long-lasting immunity, possibly lifelong (Hollinger and Emerson, 2007). In contrast, in countries with safe drinking water and proper sanitation and hygiene, resulting in very low level of HAV endemicity, infection is less common, with very few persons infected in early childhood. In those countries, the risk of outbreak with severe symptoms in the adult population is a cause for concern.

HAV is a vaccine-preventable disease. Recommendations for vaccination strategy depend on the level of endemicity in human populations: in low endemicity countries, vaccination is targeted to high-risk groups, in countries with intermediate status, large childhood vaccination is recommended by WHO, while in high endemic countries, vaccination is not recommended (Jacobsen and Wiersma, 2010; WHO, 2012). Universal vaccination in children, in intermediate endemicity areas (with improving sanitary and socio economic conditions) leads to a significant decline in incidence (Lemon et al., 2018).

HAV is a resistant virus that can persist for a long time in feces, soil, and water. $\mathrm{HAV}$ is resistant to low $\mathrm{pH}$, moderate heating $\left(60{ }^{\circ} \mathrm{C}\right.$ for 60 min) and freezing (Efsa BIOHAZ Panel, 2011).

Nowadays, with globalized food markets, food products can be produced or processed in HAV high or intermediate endemic areas, where they may be contaminated at some point of the food supply chain (Bosch et al., 2018; Miranda and Schaffner, 2019), and imported in low endemic areas. These products represent a serious source of HAV outbreaks in naïve adult populations. Hence information about risk factors should be studied worldwide. Source attribution of HAV cases is usually performed based on outbreaks data, that are not entirely representative of the general population (Bosch et al., 2018; Hu et al., 2020). Estimating pooled ORs (Odds-Ratio) or RRs (Relative Risk) from sporadic case studies, with sporadic case defined as a case that was not part of an identified outbreak, is a first step to quantitatively assess source attribution (Gonzales-Barron et al., 2019; Mughini-Gras et al., 2019).

Several meta-analyses have been performed to estimate HAV regional seroprevalence (Carrillo-Santisteve et al., 2017; Gripenberg et al., 2018; Jacobsen and Wiersma, 2010; Patterson et al., 2019). However, only two systematic reviews from case-control studies evaluate risk factors and these reviews focus specifically on exposure to sewage (Glas et al., 2001) and travel (Steffen et al., 1994).

In the present article, a systematic review and a meta-analysis were carried out to compile ORs and RRs of case-control, transversal and cohort studies, from sporadic cases, for all potential risk factors. The objective of this meta-analysis is to obtain an overall view and an estimate of the statistical significance of the different risk factors associated with sporadic HAV infections, regardless of the country of origin. The results should help to define better strategies for studying pertinent risk factors in future epidemiological studies, and confirm the relevance of current recommendations for preventing this disease.

\section{Material and methods}

The protocol of the systematic review and the meta-analysis model are described in depth in the methodological paper of this special issue (Gonzales-Barron et al., 2019).

\subsection{Systematic review}

The literature search was conducted between March 2017 and December 2017 using a combination of keywords related to (1) hepatitis A, (2) case-control OR risk factor OR cohort, (3) infection OR disease, joined by the logical connector AND. Relevant studies were identified from five bibliographic search engines, Science Direct, PubMed, Scielo, ISI Web of Science and Scopus. No restrictions were defined for the year of the study or type of publication. The search was limited to publications written in the languages English, French, Portuguese and Spanish.

Each reference record was screened for relevance for inclusion in the meta-analysis study, and subsequently, the methodological quality of the "candidate" studies were assessed using pre-set quality criteria comprising (1) appropriate selection of the controls; (2) adjustment to correct for confounders, (3) comparability between cases and controls, (4) acceptable responses rates for the exposed and control groups; (5) Data analysis appropriate to the study design; (6) provision of Odd ratio (OR) with confidence interval or p-value; or provision of sufficient data to calculate ORs; (7) overall quality of the study (Gonzales-Barron et al., 2019). Primary studies that passed the screening for relevance were marked as having potential for bias if they failed to meet at least one of the methodological quality assessment criteria. Data extracted from selected primary studies included the relevant study characteristics (location, time period, population, genotype, case definition, design, sample size of the groups, type of model, etc.), risk factors, setting, handling practices and outcome of the study OR (Odds-Ratio in case control-studies) or RR (Relative Risk in cohort or transversal studies). Outbreaks data, and epidemiological studies (eg. case-control studies) for investigating outbreaks were excluded, as non-describing sporadic cases. A data categorisation scheme was established to hierarchically group the risk factors into travel, host-specific factors and pathways of exposure (i.e., person-to-person, animal, environment and food routes (refer to Gonzales-Barron et al., 2019 for in-depth information). For hepatitis A, the variable "Population" was stratified into mixed (adults and no age specific), susceptible and children. Person-to-person transmission was stratified by the type of contact, namely contact with an ill person (mostly hepatitis or jaundice case), sex, contact related to living with children in household or living in a collectivity, being a IV drug user, and indirect contacts such as sharing towels, toothbrush or a single dining plate.

\subsection{Data synthesis}

The joint meta-analytical data was first described using basic statistics. Next, data was partitioned into meaningful categories of risk factors, such as travel, host-specific factors and person-to-person contact, animal contact, environmental exposures and food vehicles. Metaanalysis with meta-regression models were fitted to each category of risk factors, with subgroup class (e.g. travel abroad/inside) that depends on the data partition (i.g travel) (Gonzales-Barron et al., 2019).

The meta-analytical models were fitted separately by population 
type. For some food classes, the effects of handling (i.e., eating raw, undercooked) and setting (i.e., eating out) on the overall OR were assessed by the calculation of the ratio of the mean OR when food is mishandled (or, alternatively, when food is prepared outside the home) to the base OR.

The statistical analysis was designed to assess the effect of the geographical region, and takes into account the effects of the study period (before/after 2000) and the analysis type (univariate/multivariate) on the result. The objective of the region-specific meta-analysis was to inform the decision on the geographical regions that should be kept for the subsequent pooling of ORs. A Geographical region (Asia, North America, South America, Africa, Europe, Oceania) was removed from a particular meta-analysis partition only if its pooled ORs were different from those associated with the other regions or if less than 3 ORs represented the region (Gonzales-Barron et al., 2019).

All meta-analysis models were essentially weighted random-effects linear regression models, The random effect is taking into account the study effect nested into the risk factor category (Gonzales-Barron et al., 2019). Once a meta-analysis model was fitted, influential diagnostics statistics were assessed to remove any influential observation originating from studies marked as having potential-for-bias. Publication bias was assessed by funnel plots and a statistical test investigating the effect of the study sample size on the ORs (Tables 1, 2 and 3) (Gonzales-Barron et al., 2019). Heterogeneity between studies was assessed by different indicators such as the between-study variability $\left(\tau^{2}\right)$, the QE test investigating residual heterogeneity, the variance of residuals and the intra-class correlation $\mathrm{I}^{2}$ (Gonzales-Barron et al., 2019).

All analyses were produced in the R software ( $\mathrm{R}$ Development Core Team, 2008) implemented with the metafor package (Viechtbauer, 2010). The meta-analyzed risk factors are presented in summary tables only when significant. Pooled ORs were considered as significant when the lower bound of the $95 \%$ CI (Confidence Interval) was equal or greater than 1.0). Non-significant results are not given in Table 1 but in Appendix 3.

\section{Results}

\subsection{Descriptive statistics}

In the systematic review of risk factors for human infection with hepatitis A, 1624 bibliographic sources were identified using appropriate keywords in five bibliographic search engines, from which 168 case-control, transversal and cohort studies passed the full assessment for eligibility (Fig. 1). From these, 90 fully-documented case-control studies investigated the source(s) of outbreaks and were kept in the JabRef file as their data could be readily extracted (Gonzales-Barron et al., 2019). Meta-analysis was undertaken on data either extracted or calculated from 78 studies - cohort, transversal and case-control studies - focusing on sporadic cases (Fig. 1). Appendix 1 provides the references of the 78 retained publications, while Appendix 2 compiles a list of the primary studies along with their main features. Three types of studies are related with sporadic cases. The first type is seroprevalence studies with risk factors associated with infection. The second type is studies targeting high-risk population and/or specific risk factors (e.g. wastewater workers, travel, recreational activities, men who have sex with men...). The last type is studies investigating notifiable acute cases, including IgM detection, and their determinants. Among those studies, a few were investigating changes in risk factors before and after a vaccination management strategy. Only 4 studies estimated the population attributable fraction (PAF) and provided an estimate of the number of cases attributable to a given risk factor (Ciccozzi et al., 2002; Mele et al., 1997; Taylor et al., 1995; Tosti et al., 2008). Multivariate or adjusted analysis was not common for all studies (Appendix 2). The power of analysis was often low, with some studies gathering less than 100 cases (Appendix 2).

Primary studies investigated risk factors in different types of

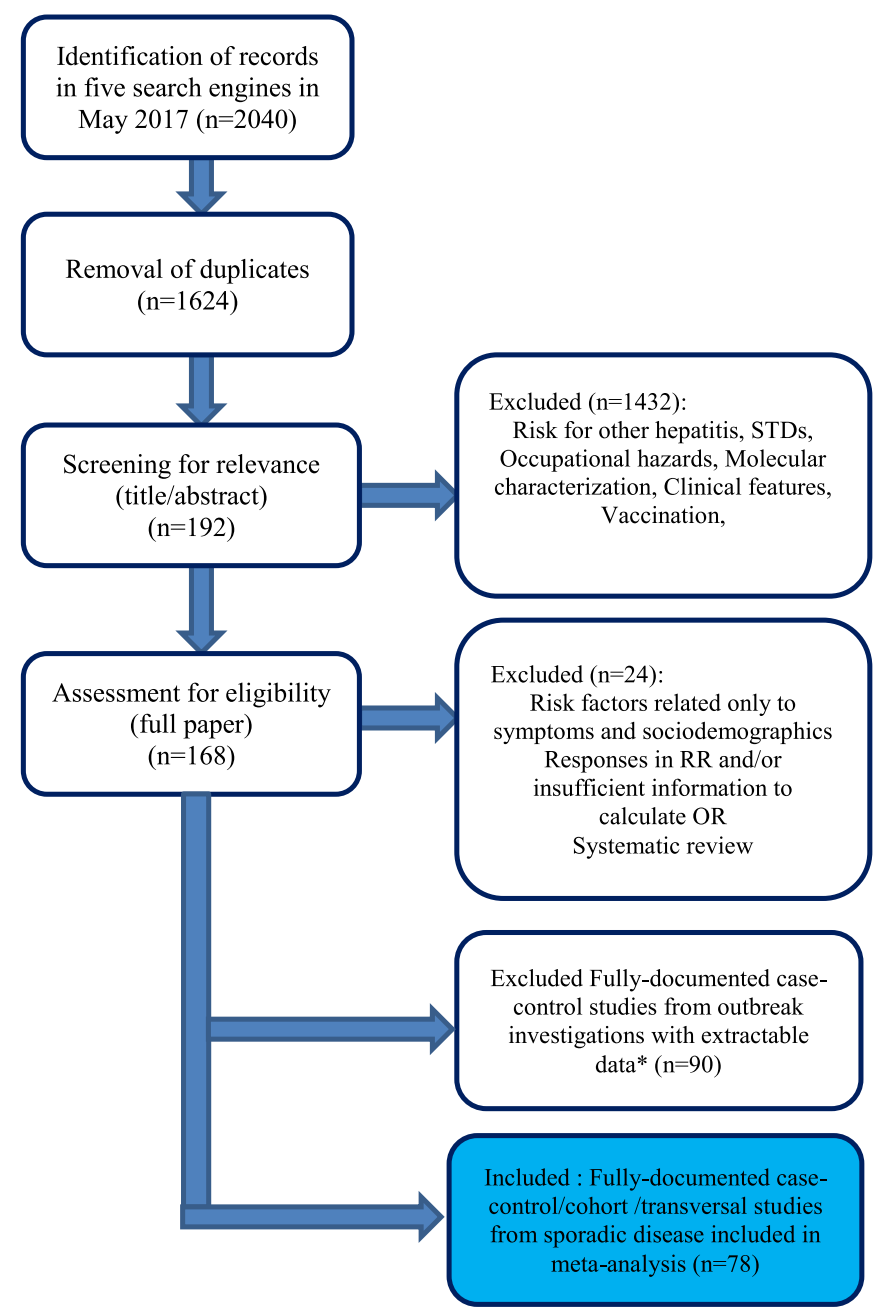

Fig. 1. PRISMA Flow chart of literature search for case-control /cohort/ transversal studies of hepatitis A infection.

population, namely children (17 studies), mixed population without age specification (58 studies), and susceptible population (3 studies), which included HIV-infected individuals (one study: (Brunet et al., 2005) and persons who inject drugs (PWID) in 2 studies (Collier et al., 2015; Luquero et al., 2009). The children included babies from their first year of life to adolescence (19 years old). If some studies focused on 1-5 or 6 years old (El-Gilany et al., 2010; Mantovani et al., 2015), the range could be as wide as 1-16 (Faillon et al., 2013), 1-18 (Halicioglu et al., 2012) or 0 to 15 years of age (Escobedo-Meléndez et al., 2012); or restricted to older children and adolescents from 5 or 6 to 19 (Barros et al., 1999; De Alencar Ximenes et al., 2008), or 4-17 years of age (Hidalgo et al., 2002Hidalgo et al., 2002).

These studies were conducted in years spanning from 1985 to 2013. About $40 \%$ of studies were published after year 2000. Study locations were, in decreasing frequency, Europe $(n=35)$, Asia $(n=17)$, North America $(n=11)$, South America $(n=9)$ and Africa $(n=6)$. Eighteen publications concerned Western Europe, including Italy $(n=10)$, France $(\mathrm{n}=5)$, the Netherlands $(\mathrm{n}=2)$ and Germany $(\mathrm{n}=1)$. We extracted a total of 426 ORs with 15 publications being the source of $50 \%$ of ORs.

Cases of hepatitis were defined using serological analysis or cases of symptomatic hepatitis confirmed by serology (Appendix 2). Among the 78 publications, 20 described symptomatic cases of hepatitis and, the others concerned serological data (Appendix 2). Symptomatic forms have been shown to be associated with age or host condition (e.g. chronic liver disease) but not to specific exposure. Hence, we make the hypothesis that risk factors are the same for both categories (definition 
of cases based with positive serology IgG or acute cases of hepatitis) and keep them together to gain statistical power of detection of risk factors.

During the methodological quality assessment, potential for bias was assigned to eleven case-control studies (Appendix 2). In Chironna et al. (2012), Ciccozzi et al. (2002), Hellara et al. (2014), Mele et al. (1997), Kim et al. (2011) and Tosti et al. (2008), the "controls/non-ill people" were affected by hepatitis B or C, while in Delarocque-Astagneau et al. (2012) and Masia et al. (2004), the controls were hepatitis E positive. In Gammie and Wyn-Jones (1997), the odds of acquiring hepatitis A from "being a surfer" was compared against "being a windsurfer", instead of "not being a surfer". In Almeida et al. (2001) the association estimates were obtained by adjusting a generalized model with a complementary $\log \log$ function. In Seo et al. (2013), the definition of cases is unclear about serology confirmation. Still, all these publications were included in the statistical analysis, though, the 83 ORs extracted from these studies were marked as having potential for bias, and their influence on the pooled OR estimate was appraised by means of the Cook's distance (Gonzales-Barron et al., 2019). If one OR from those publications had a great impact on meta-analysis result of a particular model, it was removed from the analysis (Gonzales-Barron et al., 2019).

The publications analyzed were the source of 426 ORs. The risk factors studied included environmental (155 ORs) and person-to-person transmissions ( $98 \mathrm{ORs}$ ), food (58 ORs) including poor handling practices (8 ORs), animal contact (6 ORs), travel (72 ORs), and host related factors (37 ORs) including poor personal hygiene practices (12 ORs). After further analysis, host related factors not associated with poor personal hygiene practices (13 OR) were removed from analysis, because they couldn't be considered as potential risk factors for acquiring HAV infection (i.g anti-HAV IgG detection with past history of jaundice or liver cirrhosis).

\subsection{Meta-analysis results}

All significant results of the meta-analysis are given in the Tables 1, 2 and 3. Period effect before/after 2000 was not detected as significant, or the estimate was not feasible due to too few ORs.

Travel abroad, from countries in North America, North, West and South Europe, was found a significant risk factor for the mixed population and children with pooled ORs $=4.110,95 \% \mathrm{CI}$ : (Confidence Interval): [2.716 - 6.218] and 3.059 (95\% CI: [2.347 - 3.986]) respectively. Travel was not described at the same level in all studies: some of them mentioned "travel to endemic areas", "history of travel", "far east travel", "travel in Asia", "travels to countries abroad", mixing different levels of endemicity. It was not possible to categorize traveling to a country with a low, intermediate, and high level of endemicity (and checking for its status at the time of publication). Most often, this item concerned endemic areas, with a label such as "Africa". Commonly it was not feasible to compare in the same study traveling to endemic or non-endemic countries, with some exceptions (e.g. Ciccozzi et al., 2002; Nielsen et al., 2012; Tosti et al., 2008). However, the lowest ORs concerned travel to North Europe, North Italy, or North America, and the highest ORs far East and India.

Traveling inside the country of origin was also found significant in the mixed population (with 6 ORS coming from Southern Italy and 1 from Egypt). This latter category could not be studied in children. For susceptible population, the result is not significant (pooled OR 1.176 [0.831-1.666]), with only 2 ORs were available, and therefore should be interpreted with caution .

Lack of personal hygiene (Table 1) was found significantly associated with HAV in children (pooled OR $=3.268$; 95\% CI: [1.7586.076]) but not in mixed population. In further analysis, one OR concerning "onychomachie" was excluded, because all other ORs in this category involved "bad/not washing hands" ("not washing hands after toilets" or "not washing hands after going out"). As a result, poor hygiene practices became a significant risk factor in mixed population (pooled OR $=1.606$ 95\% CI: [1.094- 2.356]. Not washing hands before preparing food preparation and cooking was only studied in 1 publication (Mausezahl et al., 1996). Gathering lack of hygiene in food preparation and not washing hands before the meal ("Poor handling", studied in 4 publications), led to a non-significant pooled $\mathrm{OR}=1.778$ [0.911-3.469] (Appendix 3).

Contact or proximity with animals (associated to low hygiene practices) (Table 1) ("poultry or animals in the kitchen", "rats in house", "no handwashing after feeding animals", "handling food", "close contact with domestic animals") in mixed population was associated with HAV. This factor could not be studied in children.

For the environmental exposure (Table 1), the following risk factors were associated with HAV in mixed and children populations: low/ untreated water consumption for the mixed population (pooled OR = 1.197, 95\% CI: [1.001 - 1.432]), and for children (pooled OR $=1.815$, 95\% CI: [1.223 - 2.694] _ forest plot in Fig. 2); contact with wastewater for the mixed population (pooled OR $=1.690,95 \%$ CI: [1.319- 2.166] and Fig. 3) and for children (pooled OR $=1.645$, 95\% CI: [1.4111.918]), and working in or attending a daycare center for the mixed population (pooled OR $=1.571,95 \%$ CI: [1.164 - 2.119] _ Fig. 4) and for children (pooled OR $=1.679,95 \%$ CI: [1.024 - 2.753] .

Recreational water activities were not associated with HAV infection, but this exposure was mixing different activities, with probable different levels of exposure, not taking into account, eg the quantity of water swallowed (Appendix 3 and Fig. 5). Rural or farm environment was a significant risk factor for adults (pooled OR $=1.710$; $95 \% \mathrm{CI}$ : [1.248-2.344]), and close to significance for children: (pooled OR = 1.363; 95\% CI: [0.966-1.924]) (Appendix 3).

Playground (or contact with soil such as during gardening) could only be tested for the mixed population, and the association with HAV was found significant (pooled OR $=2.082$; 95\% CI: [1.293- 3.350]).

Person-to-person transmission was a significant risk factor for both mixed population (pooled OR $=1.946$; $95 \%$ CI: [1.364 - 2.776]) and children (pooled OR $=3.22295 \%$ CI [2.393 - 4.338]) and could be considered for susceptible population as nearly significant (pooled OR $=1.793$; 95\% CI: [0.976-3.295]) (Appendix 3). For the mixed population, there were enough ORs to discriminate between different pathways of human-to-human transmission. Contact with a sick family member or jaundice person (household contact) was found significant (pooled OR $=3.171$; 95\% CI: [1.920- 5.236], as was being an IV drug user (pooled $\mathrm{OR}=2.206$ [1.497-3.249]), or sex activity (oral-anal sex and men who have sex with men (MSM) with pooled OR $=1.708$; 95\%\%CI: [1.3272.198]) (Table 1, forest plot in Fig. 6). Contact with children at home was not found significant (Appendix 3) (pooled OR $=1.179$, 95\%CI: [0.913-1.524]).

Indirect contact, tested only in one publication in mixed population could not be studied in this meta-analysis.

Regarding dietary risk factors, the following risk factors could be identified for the mixed population: consumption of crop products (pooled OR $=2.727 ; 95 \%$ CI: [1.406 - 5.288]), consumption of seafood products (OR $=2.398 ; 95 \%$ CI: 1.459 - 3.940]) (Table 1), in particular mollusks or shellfish (pooled OR $=2.503$; 95\% CI: [1.388- 4.515]) (Table 2 and forest plot in Fig. 7), and consumption of composite dishes outside home (pooled OR = 3.539; 95\% CI: [1.423 - 8.804]) (Table 2). Outdoors consumption of bottled water/water and ice cubes turned out to be a risk factor only for children (pooled OR $=2.032$; 95\% CI: $[1.177$ 3.508]) (Table 1). Besides, the consumption of raw seafood products increased the ORs associated with seafood by a factor of 2.277 ; $95 \% \mathrm{CI}$ : [1.198 - 4.329] (Table 3).

For all the meta-analytical models reported in Tables 1 and 2, the statistical tests indicated publication bias most often above $5 \%$ significance. The exception was observed in partitions related to "travel", "food" and "environment" in the children population. Some funnel plots are given in Fig. 8. For "environment" in children, there was an asymmetry due to a lack of non-significant studies with few ORs at the bottom of the graphs. For travel and food in children, the different categories were too heterogeneous (e.g. reported in publication as traveling in 
Table 1

Results of the meta-analysis on main risk factors.

\begin{tabular}{|c|c|c|c|c|c|c|c|c|}
\hline Population & Geogra-phical area & Risk factor & $\begin{array}{l}\text { Pooled OR } \\
{[95 \% \mathrm{CI}]}\end{array}$ & $\mathbf{N} / \mathbf{n}$ & $\begin{array}{l}\text { p-value of } \\
\text { risk factor }\end{array}$ & $\begin{array}{l}\text { Publication } \\
\text { bias p-value }\end{array}$ & $\begin{array}{l}\text { Points } \\
\text { removed } * *\end{array}$ & Heterogeneity analysis \\
\hline \multicolumn{9}{|c|}{ Travels } \\
\hline \multirow[t]{2}{*}{ Mixed } & All & Abroad & $\begin{array}{l}4.110 \\
{[2.716-} \\
6.218]\end{array}$ & $\begin{array}{l}21 / \\
49\end{array}$ & $<.0001$ & 0.302 & 4 & $\begin{array}{l}\tau^{2}=0.264 \mathrm{QE}(\mathrm{df}=54)=537.8, \mathrm{p}- \\
\mathrm{val}<0.0001 \mathrm{~s}^{2}=1.507 \mathrm{I}^{2}=14.91\end{array}$ \\
\hline & & Inside & $\begin{array}{l}2.663 \\
{[1.797-} \\
3.945]\end{array}$ & $4 / 7$ & 0.0005 & & & \\
\hline Children & All & Travels (abroad) & $\begin{array}{l}3.059 \\
{[2.347-} \\
3.986]\end{array}$ & $4 / 9$ & $<.0001$ & 0.002 & 0 & $\begin{array}{l}\tau^{2}=0.0185 \mathrm{Q}(\mathrm{df}=8)=20.19, \mathrm{p}- \\
\mathrm{val}=0.009 \mathrm{~s}^{2}=0.609 \mathrm{I}^{2}=2.947\end{array}$ \\
\hline \multicolumn{9}{|c|}{ Poor personal hygiene } \\
\hline Children & All & Poor hygiene & $\begin{array}{l}3.268 \\
{[1.758-} \\
6.076]\end{array}$ & $2 / 2$ & 0.0002 & 0.960 & 0 & $\begin{array}{l}\tau^{2}=0.383 \mathrm{QE}(\mathrm{df}=10)=40.72, \mathrm{p}- \\
\mathrm{val}<0.0001 \mathrm{~s}^{2}=0.246 \mathrm{I}^{2}=60.90\end{array}$ \\
\hline \multicolumn{9}{|c|}{ Animals \& low hygienic practices } \\
\hline Mixed & All & $\begin{array}{l}\text { Animals \& low } \\
\text { hygienic practicest }\end{array}$ & $\begin{array}{l}1.631 \\
{[1.244-} \\
2.139]\end{array}$ & $4 / 6$ & 0.0004 & 0.368 & 0 & $\begin{array}{l}\tau^{2}=0.007 \mathrm{Q}(\mathrm{df}=5)=6.310, \mathrm{p} \text {-val } \\
=0.277 \mathrm{~s}^{2}=0.291 \mathrm{I}^{2}=2.418\end{array}$ \\
\hline \multicolumn{9}{|c|}{ Environment } \\
\hline \multirow[t]{5}{*}{ Mixed } & $\begin{array}{l}\text { Africa excluded (10 } \\
\text { ORs removed) }\end{array}$ & Drink water & $\begin{array}{l}1.197 \\
{[1.001-} \\
1.432]\end{array}$ & $\begin{array}{l}8 / \\
13\end{array}$ & 0.048 & 0.692 & 0 & $\begin{array}{l}\tau^{2}=1.023 \mathrm{QE}(\mathrm{df}=86)=548.330 \\
\mathrm{p} \text {-val }<0.0001 \mathrm{~s}^{2}=0.381 \mathrm{I}^{2}= \\
72.875\end{array}$ \\
\hline & & Day care & $\begin{array}{l}1.571 \\
{[1.164-} \\
2.119]\end{array}$ & $\begin{array}{l}13 / \\
27\end{array}$ & 0.003 & & & \\
\hline & & $\begin{array}{l}\text { Farm (rural } \\
\text { residence) }\end{array}$ & $\begin{array}{l}1.710 \\
{[1.248-} \\
2.344]\end{array}$ & $7 / 8$ & 0.001 & & & \\
\hline & & Playground & $\begin{array}{l}2.082 \\
{[1.293-} \\
3.350]\end{array}$ & $2 / 3$ & 0.003 & & & \\
\hline & & Waste water & $\begin{array}{l}1.690 \\
{[1.319-} \\
2.166]\end{array}$ & $\begin{array}{l}15 / \\
37\end{array}$ & $<.0001$ & & & \\
\hline \multirow[t]{4}{*}{ Children } & All & Drink water & $\begin{array}{l}1.815 \\
{[1.223-} \\
2.694]\end{array}$ & $\begin{array}{l}8 / \\
24\end{array}$ & 0.0031 & 0.001 & 0 & $\begin{array}{l}\tau^{2}=0.754 \mathrm{QE}(\mathrm{df}=48)=259.2, \mathrm{p}- \\
\mathrm{val}<0.0001 \mathrm{~s}^{2}=0.415 \mathrm{I}^{2}=64.51\end{array}$ \\
\hline & & Day care & $\begin{array}{l}1.679 \\
{[1.024-} \\
2.753]\end{array}$ & $4 / 6$ & 0.0399 & & & \\
\hline & & Waste water & $\begin{array}{l}1.645 \\
{[1.411-} \\
1.918]\end{array}$ & $\begin{array}{l}8 / \\
19\end{array}$ & $<.0001$ & & & \\
\hline & \multicolumn{8}{|c|}{ Person-to-person by population } \\
\hline \multirow[t]{3}{*}{ All } & $\begin{array}{l}\text { South America ( } 4 \text { ORs } \\
\text { and Africa ( } 3 \text { ORs) } \\
\text { removed }\end{array}$ & Mixed & $\begin{array}{l}1.946 \\
{[1.364-} \\
2.776]\end{array}$ & $\begin{array}{l}18 / \\
70\end{array}$ & 0.0002 & 0.802 & 0 & $\begin{array}{l}\tau^{2}=0.649 \mathrm{QE}(\mathrm{df}=82)=500.069 \\
\mathrm{p} \text {-val }<0.0001 \mathrm{~s}^{2}=0.769 \mathrm{I}^{2}= \\
45.78095\end{array}$ \\
\hline & & Children & $\begin{array}{l}3.222 \\
{[2.393-} \\
4.338]\end{array}$ & $3 / 6$ & $<0.0001$ & & & \\
\hline & & & Person-to & erson 1 & type of tran & ssion & & \\
\hline \multirow[t]{3}{*}{ Mixed } & $\begin{array}{l}\text { South America ( } 2 \text { ORs } \\
\text { removed) }\end{array}$ & $\begin{array}{l}\text { Contact (jaundice } \\
\text { or hepatitis case) }\end{array}$ & $\begin{array}{l}3.171 \\
{[1.920-} \\
5.236]\end{array}$ & $\begin{array}{l}11 / \\
25\end{array}$ & $<0.0001$ & 0.730 & 0 & $\begin{array}{l}\tau^{2}=1.026 \mathrm{QE}(\mathrm{df}=64)=342.427 \\
\mathrm{p} \text {-val }<0.0001 \mathrm{~s}^{2}=0.640 \mathrm{I}^{2}= \\
61.578\end{array}$ \\
\hline & & PWID (drug user) & $\begin{array}{l}2.206 \\
{[1.497-} \\
3.249]\end{array}$ & $2 / 5$ & $<0.0001$ & & & \\
\hline & & risk sex activity & $\begin{array}{l}1.708 \\
{[1.327-} \\
2.198]\end{array}$ & $\begin{array}{l}5 / \\
23\end{array}$ & $<0.0001$ & & & \\
\hline \multirow[t]{2}{*}{ Mixed } & All & Crop Products & $\begin{array}{l}2.727 \\
{[1.406-} \\
5.288]\end{array}$ & $2 / 3$ & 0.0030 & 0.908 & 0 & $\begin{array}{l}\tau^{2}=1.739 \mathrm{QE}(\mathrm{df}=29)=431.9 \\
\mathrm{val}<0.0001 \mathrm{~s}^{2}=1.463 \mathrm{I}^{2}=54.31\end{array}$ \\
\hline & & Seafood & $\begin{array}{l}2.398 \\
{[1.459-} \\
3.940]\end{array}$ & $\begin{array}{l}11 / \\
26\end{array}$ & 0.0006 & & & \\
\hline Children & All & Beverages & $\begin{array}{l}2.032 \\
{[1.177-} \\
3.508]\end{array}$ & $3 / 4$ & 0.0109 & 0.013 & 0 & $\begin{array}{l}\tau^{2}=0.1425 \mathrm{QE}(\mathrm{df}=6)=9.831, \mathrm{p}- \\
\mathrm{val}=0.132 \mathrm{~s}^{2}=0.28 \mathrm{I}^{2}=33.728\end{array}$ \\
\hline
\end{tabular}

\footnotetext{
* Number of studies/number of ORs
} 
** Points removed by sensitivity analysis, all results are given after removing data concerned

**** Between-study variability $\left(\tau^{2}\right)$, test for residual heterogeneity (Q and $\left.\mathrm{QE}\right)$, variance of residuals $\left(\mathrm{s}^{2}\right)$, intra-class correlation $\left(\mathrm{I}^{2}\right)$

Table 2

Results of the meta-analysis on disaggregated risk factors.

\begin{tabular}{|c|c|c|c|c|c|c|c|c|}
\hline $\begin{array}{l}\text { Risk Factor } \\
\text { precise }\end{array}$ & Population & $\begin{array}{l}\text { Geographical } \\
\text { area }\end{array}$ & $\begin{array}{l}\text { Pooled OR } \\
{[95 \% \mathrm{CI}]}\end{array}$ & $\begin{array}{l}\mathbf{N} / \mathbf{n} \\
*\end{array}$ & $\begin{array}{l}\text { p-value of } \\
\text { risk factor }\end{array}$ & $\begin{array}{l}\text { Publication bias } \\
\text { p-value }\end{array}$ & $\begin{array}{l}\text { Points } \\
\text { removed }{ }^{* *}\end{array}$ & Heterogeneity analysis ${ }^{* * *}$ \\
\hline Mollusks & $\begin{array}{l}\text { Mixed \& } \\
\text { children(1OR) }\end{array}$ & All & $\begin{array}{l}2.503 \\
{[1.388-} \\
4.515]\end{array}$ & $\begin{array}{l}12 / \\
20\end{array}$ & 0.002 & 0.677 & 0 & $\begin{array}{l}\tau^{2}=0.997 \mathrm{QE}(\mathrm{df}=25)=287.7, \mathrm{p}- \\
\mathrm{val}<0.0001 \mathrm{~s}^{2}=1.196 \mathrm{I}^{2}=45.47\end{array}$ \\
\hline $\begin{array}{l}\text { Composite } \\
\text { dishes }\end{array}$ & All & All & $\begin{array}{l}3.539[1.423 \\
-8.804]\end{array}$ & $3 / 4$ & 0.007 & 0.680 & 0 & $\begin{array}{l}\tau^{2}=0.556, \mathrm{QE}(\mathrm{df}=4)=33.42, \mathrm{p}- \\
\mathrm{val}<0.0001 \mathrm{~s}^{2}=0.947 \mathrm{I}^{2}=36.97\end{array}$ \\
\hline
\end{tabular}

* Number of studies/number of ORs

** Points removed by sensitivity analysis, all results are given after removing data concerned

***: Between-study variability $\left(\tau^{2}\right)$, test for residual heterogeneity $(\mathrm{QE})$, variance of residuals $\left(\mathrm{s}^{2}\right)$, intra-class correlation $\left(\mathrm{I}^{2}\right)$

Table 3

Effect of handling on the pooled OR for seafood consumption.

\begin{tabular}{|c|c|c|c|c|c|c|c|c|}
\hline $\begin{array}{l}\text { Risk } \\
\text { Factor }\end{array}$ & Handling & $\begin{array}{l}\text { Pooled OR } \\
\text { [IC95\%] }\end{array}$ & $\begin{array}{l}\text { N/ } \\
n^{*}\end{array}$ & $\begin{array}{l}\text { p-value of } \\
\text { risk factor }\end{array}$ & $\begin{array}{l}\text { Increase in pooled } \\
\text { OR }[95 \% \mathrm{CI}]\end{array}$ & $\begin{array}{l}\text { Points } \\
\text { removed } * *\end{array}$ & $\begin{array}{l}\text { Publication bias } \\
\text { p-value }\end{array}$ & Heterogeneity analysis ${ }^{* * *}$ \\
\hline \multirow[t]{2}{*}{$\begin{array}{l}\text { Seafood } \\
\text { (at) }\end{array}$} & Raw & $\begin{array}{l}3.317[0.975- \\
11.28]\end{array}$ & $5 / 8$ & 0.0120 & $\begin{array}{l}2.277[1.198- \\
4.329]\end{array}$ & 2 & 0.949 & $\begin{array}{l}\tau^{2}=0.807 \mathrm{QE}(\mathrm{df}=23)=369.5, \mathrm{p}- \\
\mathrm{val}<0.0001 \mathrm{~s}^{2}=1.652 \mathrm{I}^{2}=32.84\end{array}$ \\
\hline & Base & $\begin{array}{l}1.456[0.814- \\
2.606]\end{array}$ & $\begin{array}{l}9 / \\
18\end{array}$ & 0.2052 & - & & & \\
\hline
\end{tabular}

(at): analysis type is significant: OR are given for multivariate analysis

* Number of studies/number of ORs

** Points removed by sensitivity analysis, all results are given after removing data concerned

Between-study variability $\left(\tau^{2}\right)$, test for residual heterogeneity $(\mathrm{QE})$, variance of residuals $\left(\mathrm{s}^{2}\right)$, intra-class correlation $\left(\mathrm{I}^{2}\right)$

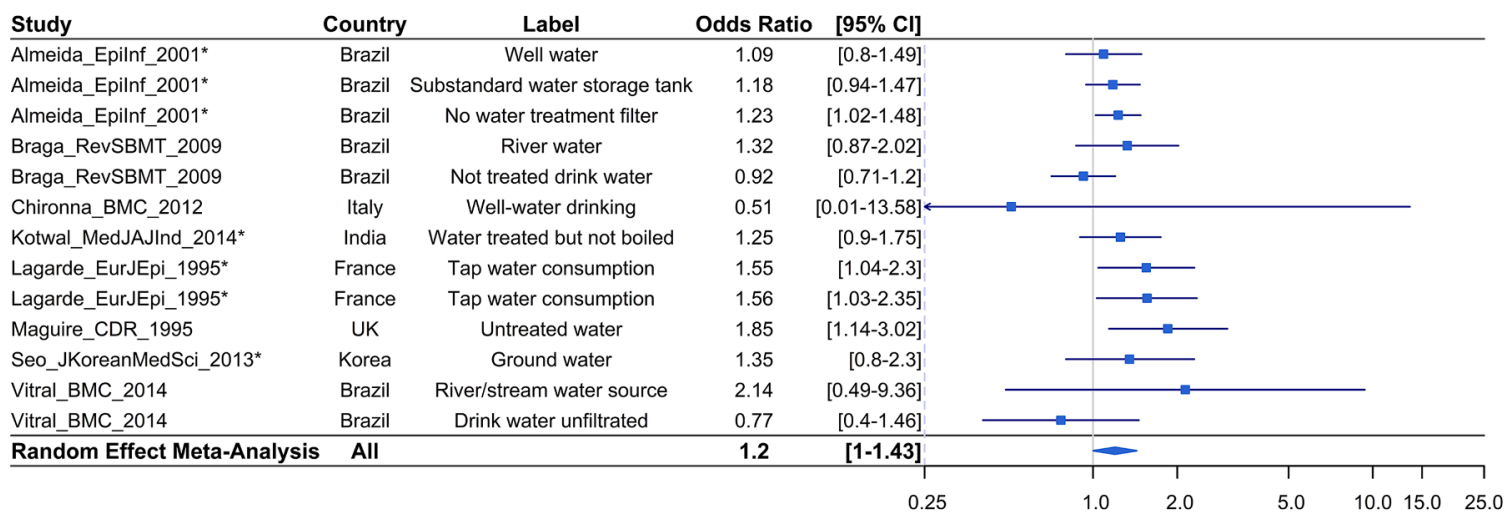

Fig. 2. Forest plot of the association of hepatitis A infection with low/untreated water consumption for mixed population

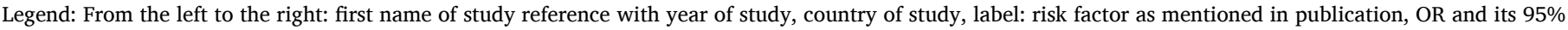
confidence interval and its graphical representation, at the bottom of the graph pooled OR estimate and its $95 \%$ confidence interval, * adjusted OR.

China, Mexico, "endemic area", "international travel") and the number of ORs, too small to get an overall trend. Furthermore, the intra-class correlation $\left(\mathrm{I}^{2}\right)$, expressed as the percentage of the total variance explained by the variation between studies, is always below high heterogeneity $(<75 \%)$ (Table 1$)$. A residual between-study heterogeneity (p-value below 0.05 for $\mathrm{Q}$ or $\mathrm{QE}$ ) was often observed for the data partitions.

\section{Discussion}

The results of this meta-analysis, based on a review of quantitative data (ORs) strengthen statistically the evidence on known risk factors for sporadic HAV infections. The results are consistent with fecal-oral transmission routes, including contact with infectious persons (household, sexual, occupational), consumption of contaminated food and water, and contact with environmental contamination such as wastewater

Travel is an important risk factor for low endemic countries. This risk factor was poorly described, often mixing different levels of endemicity, like "working abroad" or traveling "far East", hindering an interpretation based on destination's endemicity. The variability between ORs remained important, and was probably due to the heterogeneous conditions (e.g. camping) and durations of the journey.

Travel to high endemic countries is a well-known risk factor, with people visiting friends and relatives in a country of origin and returning home with HAV infection (Crowcroft, 2012; Gossner et al., 2015). HAV was also found by Steffen and Gyurech (1994) as the most frequent infection in travelers. Thus, the vaccination of travelers to endemic countries is highly recommended (Crowcroft, 2012; WHO, 2012; Wu and Guo, 2013).

In low endemic areas, HAV circulation results mostly in contamination linked to direct or indirect (i.g food handling) contact with an 


\begin{tabular}{|c|c|c|c|c|c|}
\hline Study & Country & Label & Odds Ratio & {$[95 \% \mathrm{Cl}]$} & \\
\hline Almeida_Epilnf_2001* & Brazil & Open sewer in front of house & 1.24 & {$[1.03-1.49]$} & $=$ \\
\hline Almeida_Epilnf_2001* & Brazil & No sewage system & 1.01 & {$[0.83-1.22]$} & $=$ \\
\hline Bawazir_TRSTMH_2010 & Yemen & No availability of toilet & 1.7 & {$[0.9-3.2]$} & $\rightarrow-$ \\
\hline Bawazir_TRSTMH_2010* & Yemen & No availability of toilet & 1.7 & {$[0.9-3.3]$} & $\rightarrow-$ \\
\hline Benbrik_AMPMT_2000 & France & Soiled earth polluted with sludge water & 1.85 & {$[1.17-2.93]$} & - \\
\hline Braga_RevSBMT_2009 & Brazil & Outside toilet & 2.52 & {$[1.71-3.71]$} & - \\
\hline Brugha_OEM_1998 & UK & Exposed to raw sewage & 1.61 & {$[0.89-2.9]$} & $\rightarrow-$ \\
\hline Cadilhac_EurJEpi_1996 & France & Exposure to sewage & 1.7 & {$[0.9-3]$} & - \\
\hline Cadilhac_EurJEpi_1996* & France & Exposure to sewage & 2.15 & {$[1.15-4]$} & - \\
\hline Divizia_NM_2008 & Italy & Being a sewage workers & 1.08 & {$[0.54-2.15]$} & $\rightarrow-$ \\
\hline Dounias_IntJClinPract_2006 & UK & Occupational exposure to waste & 3.21 & {$[1.65-6.25]$} & $\rightarrow$ \\
\hline Dounias_IntJClinPract_2006* & UK & Occupational exposure to waste & 3.13 & {$[1.49-6.56]$} & $\rightarrow-$ \\
\hline Karimi_ACID_2016 & Iran & Absence of sanitation wastewater & 1.42 & {$[0.42-4.77]$} & - \\
\hline Levin_AEH_2000 & Israel & Daily exposure to sewage & 1 & {$[0.3-3.5]$} & $\longrightarrow$ \\
\hline Mausezahl_IJE_1996 & China & Excrement/garbage around the house & 1.94 & {$[0.96-3.39]$} & - \\
\hline Mausezahl_IJE_1996 & China & Disposal of children stool in refuse pit or as fertilizer in the vegetable garden & 4.41 & [1.13-25] & $\longrightarrow$ \\
\hline Rachiotis_InfMed_2016 & Greece & Exposed to waste & 1.31 & {$[0.63-2.71]$} & - \\
\hline Rachiotis_IntJEnvResPubHealth_2002 & Greece & Occupational exposure to waste & 4.26 & {$[2.37-7.65]$} & -- \\
\hline Rachiotis_IntJEnvResPubHealth_2002* & * Greece & Occupational exposure to waste & 2.87 & {$[1.24-6.62]$} & $\rightarrow-$ \\
\hline Rachiotis_IntJEnvResPubHealth_2002 & Greece & Smoked/drank/ate during waste collection & 11.84 & {$[4.55-30.82]$} & $\longrightarrow$ \\
\hline Rachiotis_IntJEnvResPubHealth_2002* & * Greece & Smoked/drank/ate during waste collection & 3.85 & {$[1.34-11.06]$} & $\longrightarrow$ \\
\hline Venczel_AmJIndMed_2003 & USA & Field crew - wastewater worker & 1.59 & {$[1.09-2.32]$} & $\rightarrow$ \\
\hline Venczel_AmJIndMed_2003 & USA & Waste water treatment plant & 0.73 & {$[0.5-1.05]$} & $\rightarrow$ \\
\hline Venczel_AmJIndMed_2003 & USA & Contact with raw sewage & 0.99 & {$[0.64-1.55]$} & $\rightarrow$ \\
\hline Venczel_AmJIndMed_2003 & USA & Not always a place to wash up after work & 0.92 & {$[0.6-1.42]$} & - \\
\hline Venczel_AmJIndMed_2003 & USA & Not always use of gloves & 0.96 & {$[0.63-1.47]$} & $\rightarrow$ \\
\hline Venczel_AmJIndMed_2003 & USA & Not always use of face protection & 1.46 & {$[0.74-2.91]$} & $\rightarrow$ \\
\hline Venczel_AmJIndMed_2003 & USA & Not always eating in designated area & 1 & {$[0.65-1.54]$} & - \\
\hline Venczel_AmJIndMed_2003* & USA & Field crew - wastewater worker & 1.6 & {$[1.1-2.4]$} & $\rightarrow$ \\
\hline Weldon_JOEM_2000 & USA & Never used gloves (waste workers) & 1.47 & {$[0.68-3.19]$} & $\rightarrow$ \\
\hline Weldon_JOEM_2000 & USA & Never use face protection (waste workers) & 1.77 & {$[1.1-2.84]$} & - \\
\hline Weldon_JOEM_2000 & USA & Never ate in a lunchroom (waste workers) & 1.66 & {$[1.03-2.67]$} & $\rightarrow-$ \\
\hline Weldon_JOEM_2000 & USA & Never washed hands before meals (waste workers) & 1.77 & {$[0.74-4.23]$} & $\rightarrow-$ \\
\hline Weldon_JOEM_2000 & USA & Working in wastewater industry & 1.29 & {$[0.75-2.21]$} & - \\
\hline Weldon_JOEM_2000* & USA & Working in wastewater industry & 2 & {$[1-3.8]$} & - \\
\hline Weldon_JOEM_2000* & USA & Never ate in a lunchroom (waste workers) & 2 & {$[1.1-3.4]$} & $\rightarrow-$ \\
\hline Weldon_JOEM_2000* & USA & Never use face protection (waste workers) & 1.9 & {$[1.1-3.3]$} & - \\
\hline Random Effect Meta-Analysis & All & & 1.69 & {$[1.32-2.17]$} & 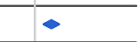 \\
\hline
\end{tabular}

Fig. 3. Forest plot of the association of hepatitis A infection with exposure to wastewater for mixed population

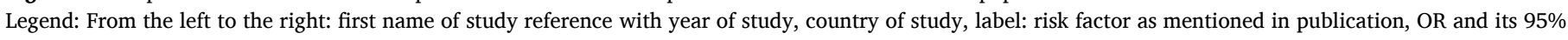
confidence interval and its graphical representation, at the bottom of the graph pooled OR estimate and its $95 \%$ confidence interval, * adjusted OR.

infected person. The most common transmission mode is person-toperson (Bosch et al., 2001; Dentinger et al., 2001; Pinto et al., 2010; Sanchez et al., 2002). Contact with an ill family member or relative, or working/attending a daycare center, particularly child daycare, are risk factors of acquiring HAV infection since asymptomatic children can excrete hepatitis A virus. Thus, working in child daycare can be considered professional exposure (Rebmann et al., 2017).

Sexual contacts, particularly involving oral-anal practices were found significant in sporadic cases, consistently with cyclic outbreaks occurring in the MSM population, such as the 2016-2017 worldwide episode, that included Europe (Ndumbi et al.,2018).

This meta-analysis could not study blood transfusion as a risk factor (only in 1 publication), even if other studies mentioned this exposure as a risk (Gallian et al., 2018, 2019). Transmission in people who injects drugs (PWID) was also documented with close promiscuity between users possibly explaining this risk factor (Hollinger and Emerson, 2007; Luquero et al., 2009).

The results confirmed the role of the lack of hygiene, and other related factors such as farm environment, gardening ("playground"), and exposure to wastewater. Hygienic practices should be more systematically studied and with more precision in epidemiological studies. Categories such as washing hands (WH) with soap (more or less frequently) after defecation, WH after going out, WH before eating, WH before preparing food, WH after work in garden or field were mostly not detailed, apart from some exceptions (eg. Mausezahl et al., 1996).

Farm environment, defined as "living in rural residence" is a risk factor probably correlated to other factors, such as unsanitary toilets, insufficient/low treatment of drinking water, not safe sewage system. Low socioeconomic status, with larger family size and crowding could also explain the result (Jacobsen and Koopman, 2004).

Exposure to contact with animals was a very heterogeneous category, with only 6 ORs belonging to 4 publications (Delarocque-Astagneau et al., 2012; Kotwal et al., 2014; Mausezahl et al., 1996; Seo et al., 2013). Two studies were showing significant (from multivariate analysis) ORS: handling food (Seo et al., 2013) and contact with domestic animals (Kotwal et al., 2014). The first study (Seo et al., 2013) concerned acute hepatitis A virus infection in the Korean population and included people handling food that were also employees in a restaurant: person-to-person transmission probably accounted for this result. The second situation ("contact with domestic animals") was not detailed in 


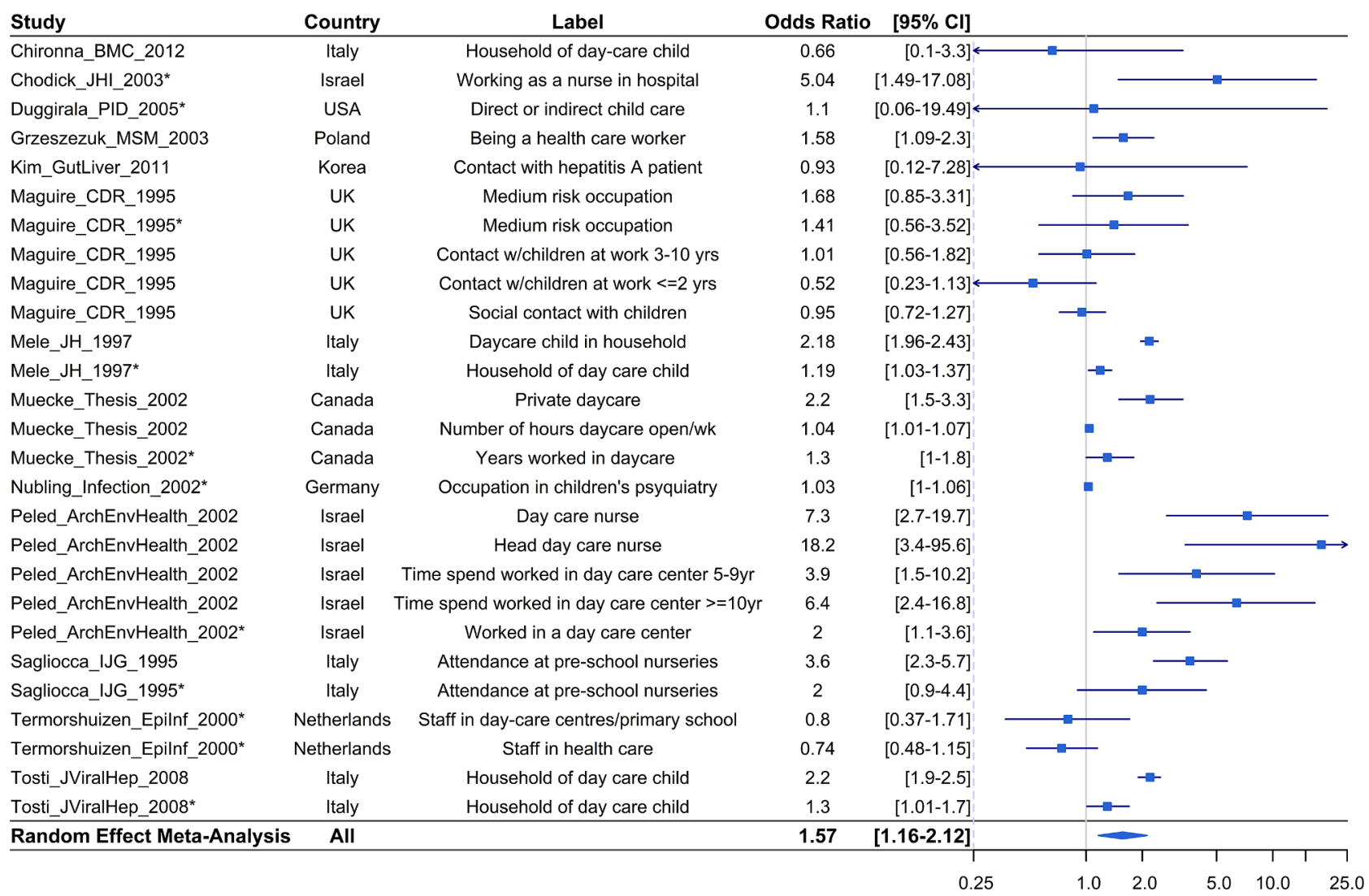

Fig. 4. Forest plot of the association of hepatitis A infection with working in day care center for mixed population

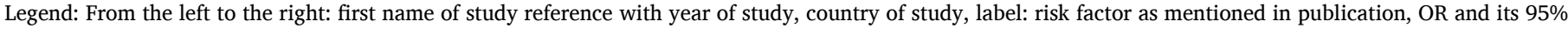
confidence interval and its graphical representation, at the bottom of the graph pooled OR estimate and its $95 \%$ confidence interval, * adjusted OR.

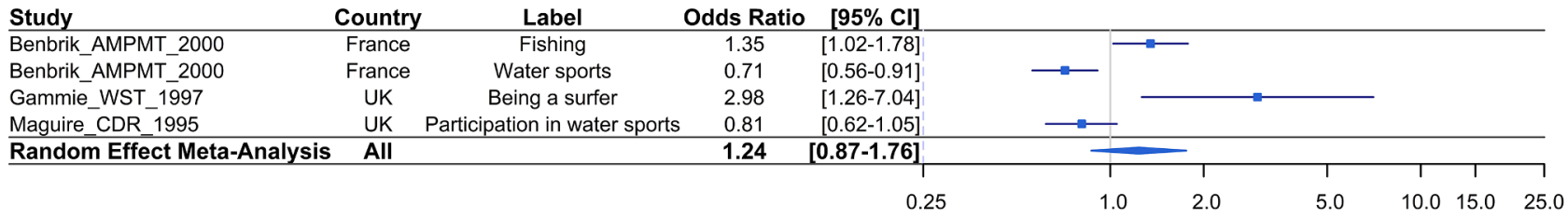

Fig. 5. Forest plot of the association of hepatitis A infection with recreational water activities for mixed population

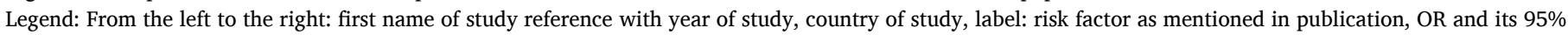
confidence interval and its graphical representation, at the bottom of the graph pooled OR estimate and its $95 \%$ confidence interval, * adjusted OR.

Kotwal et al. (2014). All other ORs, coming from univariate analyses, were not significant and could rather be a marker of low income or be associated with a lack of hygiene acting as a confounding factor. As a preliminary step, as mentioned in Seo et al. (2013), working in food handling and restaurants without being vaccinated, should be further studied, to prevent food and customers potential contamination.

For the first time, wastewater exposure was found associated with hepatitis A sporadic infections in a meta-analysis. In a previous systematic review and meta-analysis, wastewater exposure was not identified as a risk factor (Glas et al., 2001). The present meta-analysis includes several studies published after 2001. Even if heterogeneity between studies remains high (QE significant), this result is in line with the known contamination of wastewater aerosols by HAV (Brisebois et al., 2018).

HAV is a non-enveloped virus, and it can remain infectious outside host cells. It is resistant to salt and low pH (Hollinger and Emerson, 2007) and can persist in the environment, particularly in the water. Occasional waterborne outbreaks are described, like recently in Korea (Shin et al., 2017), and contamination of water is proven especially in situations of low sanitation level (Ruchusatsawat et al., 2016). Thus, it is not surprising that untreated water was associated in this meta-analysis with sporadic HAV infection. Harmonization and hierarchical categorization of untreated water could help make further recommendations and improve prevention strategies, for ground, well, individual storage, and surface/river water. Environmental studies could complete the epidemiological investigation, to explore the water contamination.

Shellfish grown in polluted water can concentrate HAV, and since depuration methods used to reduce bacterial contamination of seafood is inefficient on viruses, they represent a frequent source of outbreaks (Halliday et al., 1991; Lopalco et al., 2005; Pinto et al., 2009). Shellfish, particularly when consumed raw, was a significant risk factor in this meta-analysis. Potential contaminated shellfish areas require specific monitoring and management strategies (Thebault et al., 2012). In epidemiological studies, as shown in Fig. 7, this risk factor could be more informative for management or risk assessment if it the preparation practices (e.g. raw, lightly cooked, well- cooked), and the type (species) of shellfish (oyster, mussels, clams) were detailed.

Also, fresh vegetables can be contaminated by irrigation water, contaminated surfaces or dirty hands, as illustrated by several outbreaks in Europe linked to the consumption of semi-dried tomatoes (Gallot 


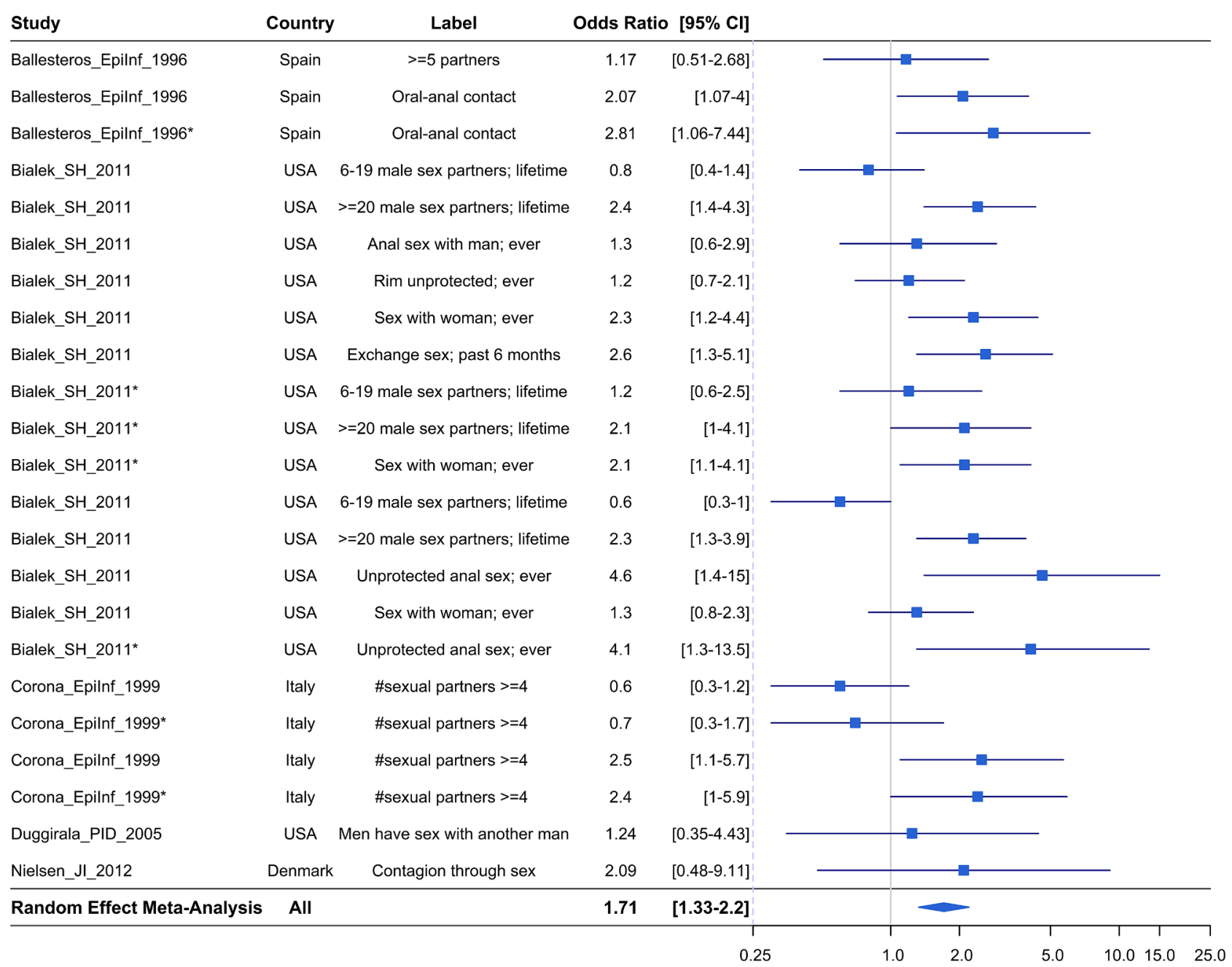

Fig. 6. Forest plot of the association of hepatitis A infection with sexual activity for mixed population

Legend: From the left to the right: first name of study reference with year of study, country of study, label: risk factor as mentioned in publication, OR and its $95 \%$ confidence interval and its graphical representation, at the bottom of the graph pooled OR estimate and its 95\% confidence interval.; * adjusted OR

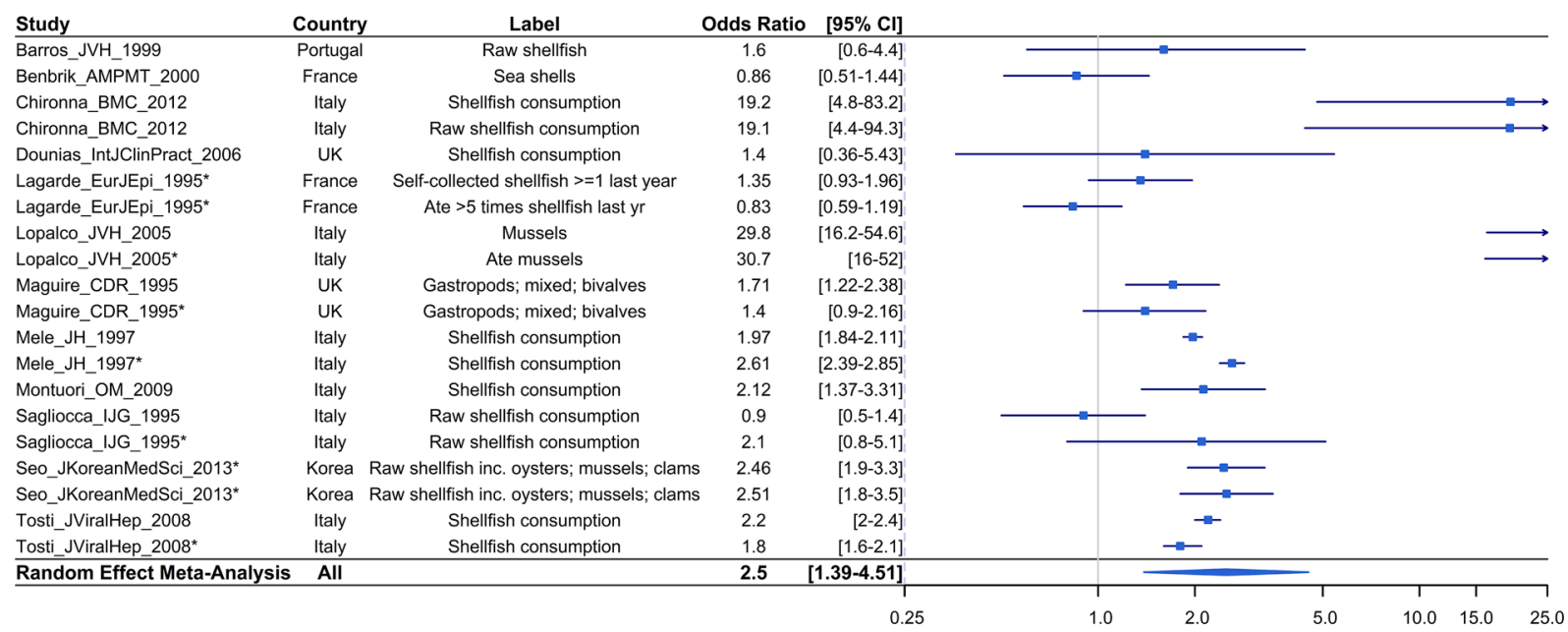

Fig. 7. Forest plot of the association of hepatitis A infection with shellfish consumption

Legend: From the left to the right: first name of study reference with year of study, country of study, label: risk factor as mentioned in publication, OR and its $95 \%$ confidence interval and its graphical representation, at the bottom of the graph pooled OR estimate and its 95\% confidence interval, * adjusted OR. 


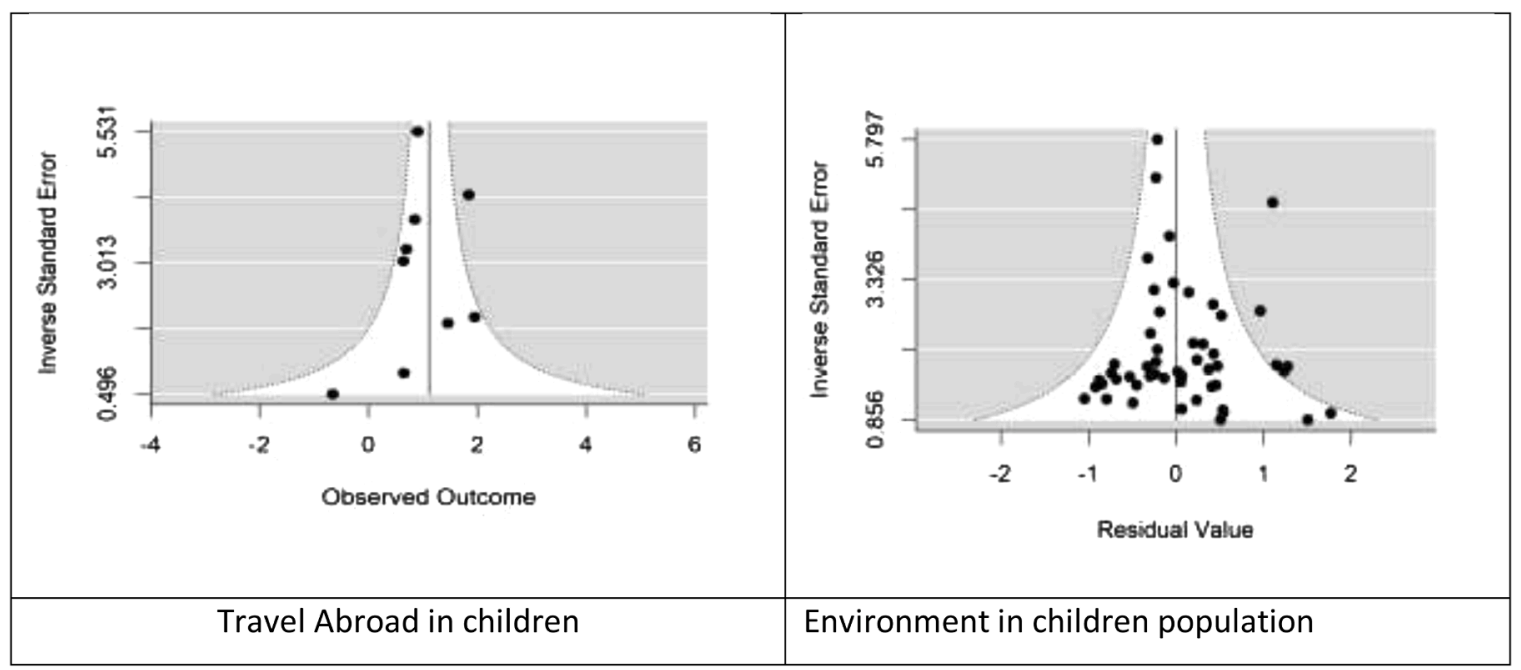

Fig. 8. Funnel plots of studies investigating categorized risk factors (travel in children, host-specific in mixed, environment, in mixed and children population) the plot shows the residuals of the model ('observed - fitted' values) on the $\mathrm{x}$-axis against their corresponding standard errors. A vertical line indicates the estimate based on the model. A pseudo confidence interval region is drawn around this value with bounds equal to $\pm 1.96 S E$, where $S E$ is the standard error value from the y-axis (assuming level $=95$ ). A lack of symmetry around the vertical line is an indicator of publication bias (see text)

et al., 2011; Petrignani et al., 2010), frozen berries (Severi et al., 2015; Tavoschi et al., 2015; Scavia et al., 2017), or with pomegranates arils in the USA (Collier et al., 2014). Food handlers, involved in harvesting or food preparation, were identified as sources of contamination in outbreaks (Rowe et al., 2009). Our results are in agreement with this potential risk for sporadic cases regarding fresh produce and composite dishes. However, we have to mention here that fresh produce (designed as "vegetables", "fresh vegetables") or composite dishes are rarely described and with few details in HAV case-control studies. Very few publications and therefore, few ORs were available for these food items. Categories such as frozen/fresh/dried, raw/cooked, washed/unwashed, prepacked/not prepacked in combination with the type of vegetables (e. g. red fruit or berries, leafy greens such as lettuce, green onion, tomatoes...) and ideally, associated with frequency of consumption should be better investigated.

Composite dishes, or food consumed outside the home, as seen in epidemiological studies in this meta-analysis, is a too broad category for risk management purpose. It would be useful to detail the type of selling (e.g. local market, street vendor, food truck, local fast food, restaurant) or the kind of food involved (e.g. fresh and raw vegetables, sandwiches, pastries...) to prioritize management strategy.

The main limitation of this meta-analysis was the data itself. There were no recent case-control studies of acute cases of HAV: only 3 studies were eligible between 2011 and 2017, against 78 between 1985 and 2017. Even if HAV is not a new disease, the level of population immunity, food and hygiene practices evolve. More raw and ready-to-eat products are consumed in developed countries within a worldwide market. As recall biases can be substantial, due to life-long immunity in studies where cases are defined based on IgG positive serology, more case-control studies on acute hepatitis cases are needed to better study potential risk factors of sporadic cases.

There was an important variability remaining after modeling between the different studies that could be due to broad definition of risk factors. Future studies should include items that are more specific, with standardized questionnaires. For example, "seafood", "crop products" or "food outside home" items are too broad definitions for food management purpose. Another critical aspect that deserves further investigation is food products' preparation process (i.e., consumed raw or cooked, vegetables washed or not). The combination of different items can be a source of unexplained variability between studies. The frequency of consumption or duration of environmental exposure was considered and could also be a source of variability. Consequently, frequency or duration effect of the risk factor could not be studied. Finally, the contamination of products/environment can differ between countries of low, middle or high endemicity and could explain remaining heterogeneity between studies.

The definition of cases is conservative, mixing serological and acute cases. As said before, it is not obvious that risk factors of infection differ so much between populations with different case definitions. This metaanalysis was made more powerful to detect significant risk factors by mixing those two categories. However, two limitations emerge from the mixing of those two types of case definitions and studies. First, the survey method, for which the quality of information is probably different between studies' types, with recall biases more critical for seroprevalence survey, causing less precise estimation of risk factors and perhaps biased with infrequent factor exposure. Second, studies evaluating HAV risk factors according to clinical presentation (asymptomatic, symptomatic but not severe, fulminant hepatitis) are lacking. It would be valuable to assess the importance of the risk factors in patients with different clinical presentations in the same epidemiological study and/ or with the same questionnaire.

Individuals at risk of severe clinical presentation, such as patients with underlying liver disease, are also under-represented in the dataset with only 3 studies among 78 (concerning treated HIV infected patients and PWID). There is a need for conducting specific studies to make robust meta-analyses to identify risk factors for these groups (WHO, 2012)

For children, including studies with a large range of ages, between 0 to 19 years of age, was needed for meta-analysis (see descriptive statistics section). Though, whenever epidemiological context confirms acquisition of infection at a young age, and if the number of children included in the epidemiological study in each class group is relevant, studying risk factors for specific age class (0-5 year old by example) would be more informative.

Distinct genetic HAV strains can be found to be associated with distinct geographical distribution (Costa-Mattioli et al., 2003). The analysis of viral sequences may help identify the source of an outbreak (Shieh et al., 2007; Wheeler et al., 2005). In few cases, typing of HAV strains has allowed identifying clusters of patients with a common origin of contamination through food consumption that had not been recognized as such from epidemiological investigations (Petrignani et al., 2010). HAV sequencing was also not included in this meta-analysis, but combining molecular and epidemiological studies could provide complementary information to better understand the risk factors. Studying 
HAV infection is still challenging in an evolving context of sanitation improvement and vaccination program strategies. For countries moving from intermediate to low endemicity, this is an opportunity to study the evolution of the importance of the risk factors in this dynamic context.

\section{Conclusion}

This meta-analysis provides an overall view of risk factors associated with sporadic HAV infection. Pooled statistical analysis from different epidemiological studies assesses their implication as significant risk factors. It confirms that HAV infections are mostly related to interhuman transmissions, either due to contact with an ill person, through oral-anal sex activity, IV drug use or lack of personal hygiene. People concerned by travels in endemic countries or occupational exposure, such as working in child daycare, or being exposed to wastewater, should be aware of their potential exposure. As HAV can persist in the environment, the fecal-oral route explains that consumption of untreated drinking water, raw shellfish consumption, and crop products are identified as risk factors of sporadic cases. However, some risk factors are under-studied such as blood transfusion or poor hygiene practices for food preparation. From the systematic review and metaanalysis, an overall hierarchical framework of risk factors, common between epidemiological studies, based on plausibility and risk management possibilities, is needed to enhance the possibilities and usefulness of future meta-analyses. In particular, the multivariate analysis could be based on the same categorization and definition of potential risk factors: comparability in time and space would be improved, and would allow robust estimates of population attributable fractions, taking into account epidemiological specificities (low/medium/high endemicity). In a context of declining seroprevalence, management or specific controls of implicated foods and water are needed, to avoid foodborne outbreaks.

\section{CRediT authorship contribution statement}

Anne Thébault: Formal analysis, Writing - original draft, Writing review \& editing. Anne-Marie Roque-Afonso: Supervision, Writing review \& editing. Pauline Kooh: Methodology, Project administration, Writing - review \& editing. Vasco Cadavez: Methodology, Investigation, Formal analysis. Ursula Gonzales-Barron: Methodology, Investigation, Formal analysis, Writing - review \& editing. Nicole Pavio: Supervision, Writing - review \& editing.

\section{Declaration of Competing Interest}

The authors declare that they have no known competing financial interests or personal relationships that could have appeared to influence the work reported in this paper.

\section{Acknowledgements}

U. Gonzales-Barron and V. Cadavez are grateful to the Foundation for Science and Technology (FCT, Portugal) and FEDER under programme PT2020 for the financial support to CIMO (UID/AGR/00690/2019).

The authors would like to thank Julie David for her useful comments and corrections. The authors would like to thank ANSES staff and the members of the ANSES Working Group on Source Attribution of Foodborne Diseases: Moez Sanaa, Laurence Watier, Jean Christophe Augustin, Frédéric Carlin, Julie David, Philippe Fravalo, Laurent Guillier, Nathalie Jourdan-Da Silva, Alexandre Leclercq, Simon Le Hello, Lapo Mughini-Gras, Isabelle Villena.

\section{Supplementary materials}

Supplementary material associated with this article can be found, in the online version, at doi:10.1016/j.mran.2020.100155.

\section{References}

Almeida, L.M.A., Werneck, G.L.A., Cairncross, S.B., Coeli, C.M.A., Costa, M.C.E.A. Coletty, P.E.A., 2001. The epidemiology of hepatitis A in Rio de Janeiro: Environmental and domestic risk factors. Epidemiol. Infect 127, 327-333.

Barros, H.A.C., Oliveira, F.B., Miranda, H.B., 1999. A survey on hepatitis A in Portuguese children and adolescents. J. Viral Hepat. 6, 249-253.

Bosch, A., Gkogka, E., Le Guyader, F.S., Loisy-Hamon, F., Lee, A., van Lieshout, L., Marthi, B., Myrmel, M., Sansom, A., Schultz, A.C., Winkler, A., Zuber, S., Phister, T., 2018. Foodborne viruses: detection, risk assessment, and control options in food processing. Int. J. Food Microbiol. 285, 110-128.

Bosch, A., Sanchez, G., Le Guyader, F., Vanaclocha, H., Haugarreau, L., Pinto, R.M., 2001. Human enteric viruses in Coquina clams associated with a large hepatitis A outbreak. Water Sci. Technol. 43, 61-65.

Brisebois, E., Veillette, M., Dion-Dupont, V., Lavoie, J., Corbeil, J., Culley, A. Duchaine, C., 2018. Human viral pathogens are pervasive in wastewater treatment center aerosols. J. Environ. Sci. (China) 67, 45-53.

Brunet, A., Grabar, S., Blanche, P., Heripret-Fredouille, L., Spiridon, G., Calboreanu, A., Rollot, F., Launay, O., Sicard, D., Salmon-Ceron, D., Abad, S., 2005. [Prevalence and risk factors of hepatitis A infection in an HIV-infected French population]. Med. Mal. Infect. 35, 73-81.

Carrillo-Santisteve, P., Tavoschi, L., Severi, E., Bonfigli, S., Edelstein, M., Bystrom, E., Lopalco, P., Panel, E.H.E., 2017. Seroprevalence and susceptibility to hepatitis A in the European Union and European Economic Area: a systematic review. Lancet Infect. Dis. 17, e306-e319.

Chironna, M.A.C., Prato, R.B.C.C., Sallustio, A.A., Martinelli, D.B.C.C., Tafuri, S.A.C.C., Quarto, M.A.C.C., Germinario, C.A.C.C., 2012. Hepatitis A in Puglia (South Italy) after 10 years of universal vaccination: Need for strict monitoring and catch-up vaccination. BMC Infect. Dis 12.

Ciccozzi, M., Tosti, M.E., Gallo, G., Ragni, P., Zotti, C., Lopalco, P., Ara, G., Sangalli, M., Balocchini, E., Szklo, A.S., Mele, A., 2002. Risk of hepatitis A infection following travel. J. Viral Hepat. 9, 460-465.

Collier, M.G., Drobeniuc, J., Cuevas-Mota, J., Garfein, R.S., Kamili, S., Teshale, E.H., 2015. Hepatitis A and B among young persons who inject drugs-vaccination, past, and present infection. Vaccine 33, 2808-2812.

Collier, M.G., Khudyakov, Y.E., Selvage, D., Adams-Cameron, M., Epson, E., Cronquist, A., Jervis, R.H., Lamba, K., Kimura, A.C., Sowadsky, R., Hassan, R. Park, S.Y., Garza, E., Elliott, A.J., Rotstein, D.S., Beal, J., Kuntz, T., Lance, S.E., Dreisch, R., Wise, M.E., Nelson, N.P., Suryaprasad, A., Drobeniuc, J., Holmberg, S.D. Xu, F., Hepatitis, A.O.I.T., 2014. Outbreak of hepatitis A in the USA associated with frozen pomegranate arils imported from Turkey: an epidemiological case study. Lancet Infect. Dis. 14, 976-981.

Costa-Mattioli, M., Di Napoli, A., Ferre, V., Billaudel, S., Perez-Bercoff, R., Cristina, J., 2003. Genetic variability of hepatitis A virus. J. Gen. Virol. 84, 3191-3201.

Crowcroft, N.S., 2012. What causes hepatitis A in travellers to endemic countries? Travel is necessary but not sufficient-a risk factor, not a cause. Epidemiol. Infect. 140, 1821-1822.

De Alencar Ximenes, R.A.A.B.K., Martelli, C.M.T.C., Merchán-Hamann, E.D., Montarroyos, U.R.A., Braga, M.C.E., De lima, M.L.C.E.F., Cardoso, M.R.A.G. Turchi, M.D.C., Costa, M.A.H., De alencar, L.C.A.A., Moreira, R.C.I., Figueiredo, G.M. J., Pereira, L.M.M.B.A., 2008. Multilevel analysis of hepatitis A infection in children and adolescents: a household survey in the Northeast and Central-west regions of Brazil. Int. J. Epidemiol 37, 852-861.

Delarocque-Astagneau, E., Abravanel, F., Moshen, A., Le Fouler, L., Gad, R.R., ElDaly, M., Ibrahim, E.M., El-Aidy, S., Lashin, T., El-Hoseiny, M., Izopet, J., Mohamed, M.K., Fontanet, A., Abdel Hamid, M., 2012. Epidemiological and virological characteristics of symptomatic acute hepatitis E in Greater Cairo, Egypt. Clin. Microbiol. Infect 18, 982-988.

Dentinger, C.M., Bower, W.A., Nainan, O.V., Cotter, S.M., Myers, G., Dubusky, L.M., Fowler, S., Salehi, E.D., Bell, B.P., 2001. An outbreak of hepatitis A associated with green onions. J. Infect. Dis. 183, 1273-1276.

Efsa BIOHAZ Panel, 2011. Scientific opinion on an update on the present knowledge on the occurrence and control of foodborne viruses. EFSA J. 9, 2190-2190.

El-Gilany, A.-H.A., Hammad, S.B., Refaat, K.C., Al-Enazi, R.D., 2010. Seroprevalence of hepatitis A antibodies among children in a Saudi community. Asian Pac. J. Trop. Med 3, 278-282.

Escobedo-Meléndez, G.A.B., Fierro, N.A.A., Roman, S.A., Maldonado-González, M.A., Zepeda-Carrillo, E.A., Panduro, A.A., 2012. Prevalence of hepatitis A, B and C serological markers in children from western Mexico. Ann. Hepatol. 11, 194-201.

Faillon, S., Martinot, A., Hau, I., Puget, A., Moulin, F., Noel, G., Guen, C.G., Lorrot, M., Callamand, P., Hue, V., Meritet, J.F., Gendrel, D., Dubos, F., 2013. Impact of travel on the seroprevalence of hepatitis A in children. J. Clin. Virol. 56, 46-51.

Gallian, P., Barlet, V., Mouna, L., Gross, S., Lecam, S., Ricard, C., Wind, F., Pouchol, E., Fabra, C., Flan, B., Visse, C., Djoudi, R., Couturier, E., de Valk, H., Tiberghien, P. Roque-Afonso, A.-M., 2018. Hepatitis A: an epidemiological survey in blood donors, France 2015 to 2017. Eurosurveillance 23, 1800237.

Gallian, P., Barlet, V., Mouna, L., Gross, S., Morel, P., Le Cam, S., Ricard, C., Maugard, C., Pouchol, E., Flan, B., Visse, C., Djoudi, R., Figoni, J., De Valk, H., Tiberghien, P., Roque-Afonso, A.-M., 2019. Persisting higher prevalence of hepatitis A virus RNA in blood donors, France, 2018. Euro Surveill. 24, 1900695.

Gallot, C., Grout, L., Roque-Afonso, A.M., Couturier, E., Carrillo-Santisteve, P., Pouey, J., Letort, M.J., Hoppe, S., Capdepon, P., Saint-Martin, S., De Valk, H., Vaillant, V., 2011. Hepatitis A associated with semidried tomatoes, France, 2010. Emerg. Infect. Dis. $17,566-567$.

Gammie, A.J.A., Wyn-Jones, A.P.B., 1997. Does hepatitis A pose a significant health risk to recreational water users? Water Sci. Technol. 35, 171-177. 
Glas, C., Hotz, P., Steffen, R., 2001. Hepatitis A in workers exposed to sewage: a systematic review. Occup. Environ. Med. 58, 762-768.

Gonzales-Barron, U., Thébault, A., Kooh, P., Watier, L., Sanaa, M., Cadavez, V., 2019. Strategy for systematic review of observational studies and meta-analysis modelling of risk factors for sporadic foodborne diseases. Microb. Risk Anal., 100082

Gossner, C.M., Severi, E., Danielsson, N., Hutin, Y., Coulombier, D., 2015. Changing hepatitis A epidemiology in the European Union: new challenges and opportunities. Euro Surveill. 20.

Gripenberg, M., Aloysia D'Cor, N., L’Azou, M., Marsh, G., Druelles, S., Nealon, J., 2018. Changing sero-epidemiology of hepatitis A in Asia Pacific countries: a systematic review. Int. J. Infect. Dis. 68, 13-17.

Halicioglu, O., Akman, S.A., Tatar, B., Atesli, R., Kose, S., 2012. Hepatitis A seroprevalence in children and adolescents aged 1-18 years among a low socioeconomic population in Izmir, Turkey. Travel Med. Infect. Dis. 10, 43-47.

Halliday, M.L., Kang, L.-Y., Zhou, T.-Z, Hu, M.-D., Pan, Q.-C., Fu, T.-Y, Huang, Y.S., S., Y., Hu., S.-L., 1991. An epidemic of hepatitis A attributable to the ingestion of raw clams in Shanghai. China. J. Infect. Dis 164, 852-859.

Hellara, O.A., Melki, W.A., Mastouri, M.B., Ben Chaabène, N.A., Loghmari, H.A., Ben Mansour, W.A., Bdioui, F.A., Safer, L.A., Saffar, H.A., 2014. Serodiagnosis of acute hepatitis in adults patients: Results of a prospective study in a central region of Tunisia [sérodiagnostic des hépatites aiguës de l'adulte: Résultats d'une étude prospective dans une région du centre tunisien]. Tunis. Med. 92, 201-207.

Hidalgo, H., A., C, M, R., Graciela, R.L., 2002. Prevalencia de hepatitis viral A y B y factores de riesgo asociados a su infección en la población escolar de un distrito de Huánuco - Perú. Rev. Peru. Med. Exp. Salud Publica 19, 5-9.

Hollinger, F.B., Emerson, S.U., 2007. Hepatitis A virus. In: Fields, B.N., Knipe, D.M. Howley, P.M (Eds.), Fields Virology. Lippincott Williams and Wilkins, Philadelphia, pp. 911-947.

Jacobsen, K.H., Koopman, J.S., 2004. Declining hepatitis A seroprevalence: a global review and analysis. Epidemiol. Infect. 132, 1005-1022.

Jacobsen, K.H., Wiersma, S.T., 2010. Hepatitis A virus seroprevalence by age and world region, 1990 and 2005. Vaccine 28, 6653-6657.

Kim, K.M., Eo, S.J., Gwak, G.-Y., Choi, M.S., Lee, J.H., Koh, K.C., Yoo, B.C., Paik, S.W., 2011. Comparison of the clinical features of hepatitis A between HBsAg-positive and HBsAg-negative patients. Gut Liver 5, 500-505.

Kotwal, A.A.B., Singh, H.C., Verma, A.K.D., Gupta, R.M.E., Jain, S.F., Sinha, S.G., Joshi, R.K.H., Teli, P.I., Khunga, V.I., Bhatnagar, A.D., Ranjan, R.K., 2014. A study of Hepatitis A and E virus seropositivity profile amongst young healthy adults in India. Med. J. Armed Forces India 70, 225-229.

Lemon, S.M., Ott, J.J., Van Damme, P., Shouval, D., 2018. Type A viral hepatitis: a summary and update on the molecular virology, epidemiology, pathogenesis and prevention. J. Hepatol. 68, 167-184.

Lopalco, P., Malfait, P., Menniti-Ippolito, F., Prato, R., Germinario, C., Chironna, M., Quarto, M., Salmaso, S., 2005. Determinants of acquiring hepatitis A virus disease in a large Italian region in endemic and epidemic periods. J. Viral Hepat. 12 (3), 315-321.

Luquero, F.J., Vallejo, F., Fuente Lde, L., Toro, C., Brugal, M.T., Bravo, M.J., Soriano, V., Barrio, G., Pulido, J., Project Itinere, G., 2009. The role of injection versus socioeconomic factors in hepatitis A virus infection among young heroin users: Implications for vaccination policies. Vaccine 27, 2674-2679.

Mantovani, S.A.S.A., Delfino, B.M.A., Martins, A.C.A., Oliart-Guzmán, H.A., Pereira, T.M. A., Branco, F.L.C.C.A., Braña, A.M.A., Filgueira-Júnior, J.A.A., Santos, A.P.A., Arruda, R.A.A., Guimarães, A.S.A., Ramalho, A.A.A., Oliveira, C.S.D.M.A., Araújo, T. S.A., Arróspide, N.C., Estrada, C.H.M.L.B., Codeço, C.T.D., Da Silva-Nunes, M.A., 2015. Socioeconomic inequities and hepatitis A virus infection in Western Brazilian Amazonian children: apatial distribution and associated factors. BMC Infect. Dis 15.

Masia, G.A.C., Orrù, G.A., Floris, L.B., Massa, F.A., Grondona, L.A., Cusano, B.A., Gallus, A.R.A., Coppola, R.C.A., 2004. Changing patterns in the seroepidemiology of hepatitis viruses in Sardinian young adults. J. Prev. Med. Hyg 45, 21-26.

Mausezahl, D., Cheng, F., Zhang, S., Tanner, M., 1996. Hepatitis a in a Chinese urban population: The spectrum of social and behavioural risk factors. Int. J. Epidemiol. $25,1271-1279$

Mele, A., Stroffolini, T., Palumbo, F., Gallo, G., Ragni, P., Balocchini, E., Tosti, M.E., Corona, R., Marzolini, A., Moiraghi, A., 1997. Incidence of and risk factors for hepatitis A in Italy: public health indications from a 10-year surveillance. J. Hepatol. $26,743-747$.

Miranda, R.C., Schaffner, D.W., 2019. Virus risk in the food supply chain. Curr Opin Food Sci. 30, 43-48.

Mughini-Gras, L., Kooh, P., Fravalo, P., Augustin, J.-C., Guillier, L., David, J., Thébault, A., Carlin, F., Leclercq, A., Jourdan-Da-Silva, N., Pavio, N., Villena, I., Sanaa, M., Watier, L., 2019. Critical orientation in the jungle of currently available methods and types of data for source attribution of foodborne diseases. Front. Microbiol. 10.

Ndumbi, P., Freidl, G.S., Williams, C.J., Mårdh, O., Varela, C., Avellón, A., Friesema, I., Vennema, H., Beebeejaun, K., Ngui, S.L., Edelstein, M., Smith-Palmer, A., Murphy, N., Dean, J., Faber, M., Wenzel, J., Kontio, M., Müller, L., Midgley, S.E., Sundqvist, L., Ederth, J.L., Roque-Afonso, A.-M., Couturier, E., Klamer, S. Rebolledo, J., Suin, V., Aberle, S.W., Schmid, D., De Sousa, R., Augusto, G.F., Alfonsi, V., Del Manso, M., Ciccaglione, A.R., Mellou, K., Hadjichristodoulou, C., Donachie, A., Borg, M.-L., Sočan, M., Poljak, M., Severi, E., Team MotEHAOI, 2018. Hepatitis A outbreak disproportionately affecting men who have sex with men (MSM) in the European Union and European Economic Area, June 2016 to May 2017. Eurosurveillance 23 (33), 1700641.

Nielsen, U.S., Thomsen, R.W., Cowan, S., Larsen, C.S., Petersen, E., 2012. Predictors of travel-related hepatitis A and B among native adult Danes: A nationwide case-control study. J. Infect. 64, 399-408.
Patterson, J., Abdullahi, L., Hussey, G.D., Muloiwa, R., Kagina, B.M., 2019. A systematic review of the epidemiology of hepatitis A in Africa. BMC Infect. Dis. 19, 651.

Petrignani, M., Harms, M., Verhoef, L., van Hunen, R., Swaan, C., van Steenbergen, J., Boxman, I., Peran, I.S.R., Ober, H., Vennema, H., Koopmans, M., van Pelt, W., 2010. Update: a food-borne outbreak of hepatitis A in the Netherlands related to semi-dried tomatoes in oil, January-February 2010. Euro Surveill. 15.

Pinto, R.M., Costafreda, M.I., Bosch, A., 2009. Risk assessment in shellfish-borne outbreaks of hepatitis A. Appl. Environ. Microbiol. 75, 7350-7355.

Pinto, R.M., Costafreda, M.I., Perez-Rodriguez, F.J., D’Andrea, L., Bosch, A., 2010. Hepatitis A virus: state of the art. Food Environ. Virol. 127-135.

$\mathrm{R}$ development Core Team, 2008. Foundation for statistical computing, Vienna, Austria ISBN 3-900051-07-0. http://www.R-project.org.

Rebmann, T., Baskin, C.R., Loux, T.M., Wakefield, M., 2017. Uptake and attitudes regarding hepatitis A vaccine among childcare centre staff, administrators, and parents. Public Health 142, 152-158.

Robertson, B.H., Jansen, R.W., Khanna, B., Totsuka, A., Nainan, O.V., Siegl, G., Widell, A., Margolis, H.S., Isomura, S., Ito, K., et al., 1992. . Genetic relatedness of hepatitis A virus strains recovered from different geographical regions. J. Gen. Virol. 73 (Pt 6), 1365-1377.

Rowe, S.L., Tanner, K., Gregory, J.E., 2009. Hepatitis a outbreak epidemiologically linked to a food handler in Melbourne, Victoria. Commun. Dis. Intell. Q. Rep. 33, $46-48$.

Ruchusatsawat, K., Wongpiyabovorn, J., Kawidam, C., Thiemsing, L., Sangkitporn, S., Yoshizaki, S., Tatsumi, M., Takeda, N., Ishii, K., 2016. An outbreak of acute Hepatitis caused by genotype IB Hepatitis A viruses contaminating the water supply in Thailand. Intervirology 59, 197-203.

Sanchez, G., Pinto, R.M., Vanaclocha, H., Bosch, A., 2002. Molecular characterization of hepatitis a virus isolates from a transcontinental shellfish-borne outbreak. J. Clin. Microbiol. 40, 4148-4155.

Scavia, G., Alfonsi, V., Taffon, S., Escher, M., Bruni, R., De Medici, D., Pasquale, S., Guizzardi, S., Cappelletti, B., Iannazzo, S., Losio, N., Pavoni, E., Decastelli, L., Ciccaglione, A., Equestre, M., Tosti, M., Rizzo, C., 2017. A large prolonged outbreak of hepatitis A associated with consumption of frozen berries, Italy, 2013-14. J. Med. Microbiol. 66 (3), 342-349.

Seo, J.Y.A., Choi, B.Y.A., Ki, M.B., Jang, H.L.A., Park, H.S.A., Son, H.J.C., Bae, S.H.D., Kang, J.H.E., Jun, D.W.F., Lee, J.-W.G., Hong, Y.J.H., Kim, Y.S.I., Kim, C.-H.J., Chang, U.I.D., Kim, J.-H.K., Yang, H.W.L., Kim, H.S.M., Park, K.B.N., Hwang, J.S.O., Heo, J.P., Kim, I.K.Q., Kim, J.S.R., Cheon, G.J.S., 2013. Risk factors for acute hepatitis a infection in Korea in 2007 and 2009: A case-control study. J. Korean Med. Sci. 28, 908-914.

Severi, E., Verhoef, L., Thornton, L., Guzman-Herrador, B.R., Faber, M., Sundqvist, L., Rimhanen-Finne, R., Roque-Afonso, A.M., Ngui, S.L., Allerberger, F., BaumannPopczyk, A., Muller, L., Parmakova, K., Alfonsi, V., Tavoschi, L., Vennema, H., Fitzgerald, M., Myrmel, M., Gertler, M., Ederth, J., Kontio, M., Vanbockstael, C., Mandal, S., Sadkowska-Todys, M., Tosti, M.E., Schimmer, B., J, O.G., SteneJohansen, K., Wenzel, J.J., Jones, G., Balogun, K., Ciccaglione, A.R., L, O.C., Vold, L., Takkinen, J., Rizzo, C., 2015. Large and prolonged food-borne multistate hepatitis A outbreak in Europe associated with consumption of frozen berries, 2013 to 2014. Euro Surveill. 20, 21192.

Shieh, Y.C., Khudyakov, Y.E., Xia, G., Ganova-Raeva, L.M., Khambaty, F.M., Woods, J. W., Veazey, J.E., Motes, M.L., Glatzer, M.B., Bialek, S.R., Fiore, A.E., 2007. Molecular confirmation of oysters as the vector for hepatitis A in a 2005 multistate outbreak. J. Food Prot. 70, 145-150.

Shin, E., Kim, J.S., Oh, K.H., Oh, S.S., Kwon, M., Kim, S., Park, J., Kwak, H.S., Chung, G. T., Kim, C.J., Kim, J., 2017. A waterborne outbreak involving hepatitis A virus genotype IA at a residential facility in the Republic of Korea in 2015. J. Clin. Virol. 94, 63-66.

Steffen, R., Gyurech, D., 1994. Advances in hepatitis A prevention in travellers. J. Med. Virol. 44, 460-462.

Steffen, R., Kane, M.A., Shapiro, C.N., Billo, N., Schoellhorn, K.J., van Damme, P., 1994. Epidemiology and prevention of hepatitis A in travelers. JAMA 272, 885-889.

Tavoschi, L., Severi, E., Niskanen, T., Boelaert, F., Rizzi, V., Liebana, E., Gomes Dias, J., Nichols, G., Takkinen, J., Coulombier, D., 2015. Food-borne diseases associated with frozen berries consumption: a historical perspective, European Union, 1983 to 2013. Euro Surveill. 20, 21193.

Taylor, M.B., Becker, P.J., Van Rensburg, E.J., Harris, B.N., Bailey, I.W., Grabow, W.O.K., 1995. A serosurvey of water-borne pathogens amongst canoeists in South Africa. Epidemiol. Infect. 115, 299-307.

Thebault, A., Le Saux, J.C., Pommepuy, M., Le Guyader, S., Lailler, R., Denis., J.B., 2012. Quantitative approach of risk management strategies for hepatitis a viruscontaminated oyster production areas. J. Food Protect. 75 (7), 1249-1257.

Tosti, M.E.A.C., Spada, E.A., Romanò, L.B., Zanetti, A.B., Mele, A.A., 2008. Acute hepatitis A in Italy: incidence, risk factors and preventive measures. J. Viral Hepat. $15,26-32$.

Viechtbauer, W., 2010. Conducting Meta-Analyses in R with the metafor Package. 2010 $36,48$.

Wheeler, C., Vogt, T.M., Armstrong, G.L., Vaughan, G., Weltman, A., Nainan, O.V., Dato, V., Xia, G., Waller, K., Amon, J., Lee, T.M., Highbaugh-Battle, A., Hembree, C., Evenson, S., Ruta, M.A., Williams, I.T., Fiore, A.E., Bell, B.P., 2005. An outbreak of hepatitis A associated with green onions. N. Engl. J. Med. 353, 890-897.

WHO, 2012. WHO position paper on hepatitis A vaccines - June 2012. Wkl. Epidemiol. Records 28-29, 261-276.

WHO 2015. Hepatitis A. Last Acces 27th August 2020 https://www.who.int/immunizati on/diseases/hepatitisA/en/. 
WHO 2020. Hepatitis A. Last Acces 27th August 2020. https://www.who.int/news -room/fact-sheets/detail/hepatitis-a.

Wu, D., Guo, C.Y., 2013. Epidemiology and prevention of hepatitis A in travelers. J. Travel Med. 20, 394-399.
Hu, X., Collier, M.G., Xu, F., 2020. Hepatitis A outbreaks in developed countries: detection, control, and prevention. Foodborne Pathog. Dis. 17, 166-171. 